\title{
Sobrevivência/viabilidade de bovinos com Hematúria Enzoótica após transferência para região livre de Pteridium arachnoideum ${ }^{1}$
}

\author{
Alexandre Galvão², Marilene de Farias Brito³, Ana Paula Aragão², Elise Miyuki Yamasaki², \\ Paulo Vargas Peixoto ${ }^{4}$ e Carlos Hubinger Tokarnia ${ }^{4}$
}

\begin{abstract}
Galvão A., Brito M.F., Aragão A.P., Yamasaki E.M., Peixoto P.V. \& Tokarnia C.H. 2012. [Survival/viability of cattle with Bovine Enzootic Hematuria after transfer to area free of Pteridium arachnoideum.] Sobrevivência/viabilidade de bovinos com Hematúria Enzoótica após transferência para região livre de Pteridium arachnoideum. Pesquisa Veterinária Brasileira 32(9):887-902. Projeto Sanidade Animal Embrapa/UFRRJ, Seropédica, RJ 23890-000, Brazil. E-mail: tokarnia@ufrrj.br

With the objective of explaining the question of survival of cattle affected by Enzootic Hematuria, when transferred to areas free of Pteridium arachnoideum, the study was accomplished in two parts: a) by a questionnaire regarding the epidemic aspects of that illness, which was answered by the proprietors of 73 cattle establishments visited in the areas of Southeast of Brazil, where P. arachnoideum is prevalent. The applied questionnaire to the proprietors indicates that enzootic hematuria is responsible for serious socioeconomic problems; b) clinical and laboratorial attendance of 51 cattle of this area affected by Enzootic Hematuria, between 2007 and 2011, transferred to area free of P. arachnoideum. More than $90 \%$ of the affected animals by HEB died before two years after removal from areas free of $P$. arachnoideum.
\end{abstract}

INDEX TERMS: Pteridium arachnoideum, Enzootic Hematuria, cattle.

RESUMO.- Com o objetivo de esclarecer a questão da sobrevida de bovinos afetados por Hematúria Enzoótica, quando transferidos para áreas livres de Pteridium arachnoideum, o estudo foi realizado em duas partes: a) aplicação de questionário versando sobre os aspectos epidemiológicos dessa enfermidade, respondido por proprietários de 73 estabelecimentos pecuários visitados nas áreas da Região Sudeste onde $P$. arachnoideum é prevalente. 0 questionário aplicado aos proprietários indica que a HEB é causa de sérios problemas sócio-econômicos. b) acompanhamento clínico e laboratorial de 51 bovinos desta região, afetados pela Hematúria Enzoótica entre 2007 e 2011, transferidos para região livre de $P$. arachnoideum. Verificou-se que mais de $90 \%$ dos animais afetados por HEB morre antes de dois

\footnotetext{
${ }^{1}$ Recebido em 26 de abril de 2012.

Aceito para publicação em 6 de junho de 2012.

Parte da Tese de Doutorado do primeiro autor.

${ }^{2}$ Doutorando do Curso de Pós-Graduação em Ciências Veterinárias, área de concentração em Sanidade Animal, Universidade Federal Rural do Rio de Janeiro (UFRRJ), BR 465 Km 7, Seropédica, RJ 23890-000, Brasil.

${ }^{3}$ Departamento de Epidemiologia e Saúde Pública, Instituto de Veterinária, UFRRJ, Seropédica, RJ.

${ }^{4}$ Departamento de Nutrição Animal e Pastagem, Instituto de Zootecnia, UFRRJ, Seropédica, RJ. *Autor para correspondência: tokarnia@ufrrj.br
}

anos após serem transferidos para áreas indenes de P. arachnoideum.

TERMOS DE INDEXAÇ̃̃O: Pteridium arachnoideum, Hematúria Enzoótica, bovinos.

\section{INTRODUÇÃO}

Popularmente mais conhecidas como "samambaias", Pteridium spp. estão entre as plantas tóxicas mais importantes do mundo, dada à distribuição cosmopolita e, principalmente, pelo seu alto potencial carcinogênico para animais e seres humanos. Esse efeito carcinogênico se dá pela presença de um norsesquiterpeno denominado ptaquilosídeo, princípio tóxico de ação radiomimética, cuja ação pode variar em função da espécie animal, do tempo de ingestão e da quantidade diária ingerida. Em bovinos, a ingestão prolongada de samambaia provoca dois quadros patológicos devidos à ação cancerígena. 0 mais importante, sob o ponto de vista econômico, é a Hematúria Enzoótica Bovina (HEB), condição determinada pelo surgimento de processos neoplásicos e hiperplásicos na parede da bexiga; o outro quadro, também associado a significativos prejuízos econômicos, é representado pelos carcinomas das vias digestivas superiores. Além dessas duas doenças, a ingestão 
de samambaia ainda causa uma doenças de evolução aguda, a Diátese Hemorrágica (DH) (Tokarnia et al. 2012).

Em regiões severamente invadidas por Pteridium spp. os prejuízos econômicos são muito significativos, em especial, na pecuária de leite. Em algumas propriedades no Brasil até $90 \%$ das vacas de leite "urinam sangue" (França et al. 2002). 0 problema é tão sério que, nessas áreas muito infestadas, alguns produtores abandonam a pecuária. Além disso, é recorrente a atividade de "passar o problema", isso é, os proprietários vendem vacas com HEB para outros menos avisados. A situação agrava-se ainda mais porque os métodos de controle da planta, em geral, são pouco eficientes.

Um dos aspectos pouco claros a respeito da HEB refere-se à sobrevida e à capacidade de recuperação de bovinos por ela acometidos quando deixam de ingerir Pteridium spp. De acordo com Gründer (2002), a retirada dos animais dos pastos invadidos por $P$. aquilinum e boa alimentação, levaria a uma lenta recuperação, mas não haveria cura completa. Os animais poderiam alcançar idade avançada, porém permaneceriam antieconômicos. Após nova ingestão da planta, a hematúria recidivaria rapidamente.

Observações de campo, todavia, indicam que a maior parte dos animais afetados por essa forma da enfermidade, morre (Galvão 2007, dados não publicados). 0 presente estudo foi realizado, sobretudo, para esclarecer até que ponto podem se recuperar bovinos acometidos por HEB, quando retirados de campos invadidos pela planta.

0 estudo compreendeu duas partes. Uma foi o levantamento epidemiológico da hematúria enzoótica em 73 propriedades rurais visitadas em região com alta incidência da doença, no sul dos estados do Rio de Janeiro e de Minas Gerais e no norte do estado de São Paulo e a outra pelo acompanhamento clínico e laboratorial de 51 bovinos afetados pela doença, e transferidos de áreas infestadas para área indene de Pteridium arachnoideum.

\section{MATERIAL E MÉTODOS}

\section{Levantamento epidemiológico}

Os dados referentes à epidemiologia da Hematúria Enzoótica Bovina (HEB) foram levantados através de um questionário (vide p.901) aplicado durante visitas a 73 propriedades rurais em municípios do sul dos estados do Rio de Janeiro e de Minas Gerais, e do norte do estado de São Paulo.

\section{Animais}

No período compreendido entre 29 de setembro de 2007 e 15 de janeiro de 2011, foram estudados 51 casos de intoxicação crônica por Pteridium arachnoideum, sob a forma clínica de HEB. Os animais foram adquiridos para o estudo por apresentarem HEB clínica ou porque, segundo o proprietário, tinham histórico anterior de hematúria. 0 presente estudo foi realizado em duas situações diferentes, identificados como Grupo I e Grupo II.

0 Grupo I foi constituído por 26 bovinos (numerados do 1 ao 27, exceto o número 6); 24 eram fêmeas e dois eram machos, sem raça definida, de diferentes faixas etárias, oriundos de sete propriedades distintas (Propriedades A-G), todas localizadas no município de Passa Vinte, MG, com altitudes que variavam de 700 a 900 metros e graus de invasão por $P$. arachnoideum variando de 60 a $90 \%$ da área.
Os animais foram transferidos para a Fazenda Grupo I, uma propriedade no município de Quatis, RJ, em excelentes condições de pastagem, constituída por Brachiaria brizanta e B. mutica, numa várzea às margens do Rio Paraíba do Sul, a uma altitude aproximada de 400 metros. Ao chegarem, os animais foram identificados com brincos plásticos numerados, submetidos a testes de Brucelose e de Tuberculose, vacinados contra a Febre Aftosa e Raiva e vermifugados com abamectina $1 \%$.

As datas de chegada dos animais e sua origem foram as seguintes: Propriedade A (Bovinos 1-5), dia 29.9.2007; Propriedade B (Bovinos 7-10), dia 29.9.2007; Propriedade C (Bovinos 11-14), em 15.1.2008; Propriedade D (Bovinos 15-19), no dia 16.6.2008; Propriedade E (Bovino 20), dia 10.5.2009; Propriedade F (Bovinos 2125), dia 17.7.2009, e Propriedade G (Bovinos 26-27), dia 6.9.2008.

0 Grupo II foi constituído por 25 vacas e novilhas da raça Girolanda (Bovinos 28-52), com alto potencial na produção de leite, oriundas de uma mesma propriedade com aproximadamente 900 metros de altitude, e com cerca de $80 \%$ dos pastos invadidos pela samambaia, localizada no distrito de Mauá (Propriedade $\mathrm{H}$ ), município de Resende, RJ. Os animais foram transferidos no dia 28.7.2006 para a Fazenda Grupo II, localizada às margens da Rodovia Presidente Dutra no município de Resende, RJ, a uma altitude aproximada de 400 metros. A alimentação constava de ração balanceada, bagaço de cevada e capim elefante (Pennisetum purpureum) picado no cocho, além de pastagem de Brachiaria decumbens. Neste Grupo, o acompanhamento clínico do rebanho e análise dos registros zootécnicos da propriedade foram realizados no período compreendido entre junho de 2008 e maio de 2011.

\section{Exames}

Exames clínicos. Os animais dos Grupos I e II foram avaliados quanto ao comportamento, a condição corporal (CC): CC 1 (magra), CC 2 (moderada) e CC 3 (gorda), e quanto ao tipo de hematúria clínica: contínua ou intermitente. Essa avaliação foi realizada em intervalos que variaram no primeiro ano a cada 15 dias e nos anos seguintes a cada 60 dias.

Exames laboratoriais. Foram realizados exames laboratoriais apenas nos animais do Grupo I. A avaliação dos parâmetros hematológicos (hemograma completo) foram realizados com amostras pareadas obtidas durante a observação clínica, por punção da veia coccígea, utilizando-se agulhas descartáveis calibre $30 \times 8 m m$, e acondicionadas em frascos à vácuo, com e sem anticoagulante (EDTA).

Amostras de urina formam colhidas em frascos próprios para urinálise, mantidas sob refrigeração e avaliadas através de fita reagente $\left(\right.$ Hemagen $^{\circledR}$ ) e pela sedimentoscopia.

Os exames laboratoriais foram realizados numa primeira etapa no Laboratório de Patologia Clínica do Instituto de Veterinária da Universidade Federal do Rio de Janeiro (UFRRJ), Seropédica, RJ, e posteriormente no laboratório de Análises Clínicas Marins, em Resende, RJ.

Necropsias e exames histológicos. As necropsias e os exames histológicos foram realizados somente nos animais do Grupo I. Dos 26 animais do Grupo I, 19 foram necropsiados ou, pelo menos, tiveram as bexigas colhidas para exame histopatológico, durante o abate. No decorrer da necropsia foram coletados fragmentos de todos os órgãos em solução de formalina 10\% tamponada. Todo material coletado foi processado rotineiramente, e após inclusão em parafina, foram confeccionados cortes com espessura de $5 \mu$, corados pela hematoxilina e eosina e examinados em microscópio óptico. 0 processamento do material foi realizado nas instalações do setor de Anatomia Patológica do Projeto Sanidade Animal, convênio Embrapa/UFRRJ. 


\section{RESULTADOS Levantamento epidemiológico}

O levantamento epidemiológico realizado revelou casos de Hematúria Enzoótica em 71 (97\%) das 73 propriedades visitadas, localizadas em oito diferentes regiões no município de Natividade da Serra, SP (distritos de Monte Alegre, Selado, Caeté e Catussaba), município de Bocaina de Minas, MG (distritos Santana, Piedade, Sertão, Mirantão, Furnas e Santo Antônio), município de Passa Vinte, MG (distritos de Cuba, Carlos Euler, Mato Dentro, Rio das Pedras e Espraia- do) e município de Resende, RJ (distritos de Mauá, Bagagem, Rio Preto e Jacuba). A grande maioria era constituída de pequenos e médios estabelecimentos que desenvolviam como principal atividade a produção de leite. A maioria das propriedades (44) tinha mais de $70 \%$ das áreas de pastagem invadidas por Pteridium arachnoideum, 23 propriedades estavam com aproximadamente $50 \%$ da área total invadida e somente seis, tinham menos que $30 \%$ do pasto dominado por samambaia; em 66 propriedades os pastos eram roçados durante o ano. (Fig.1 e 2A,B)
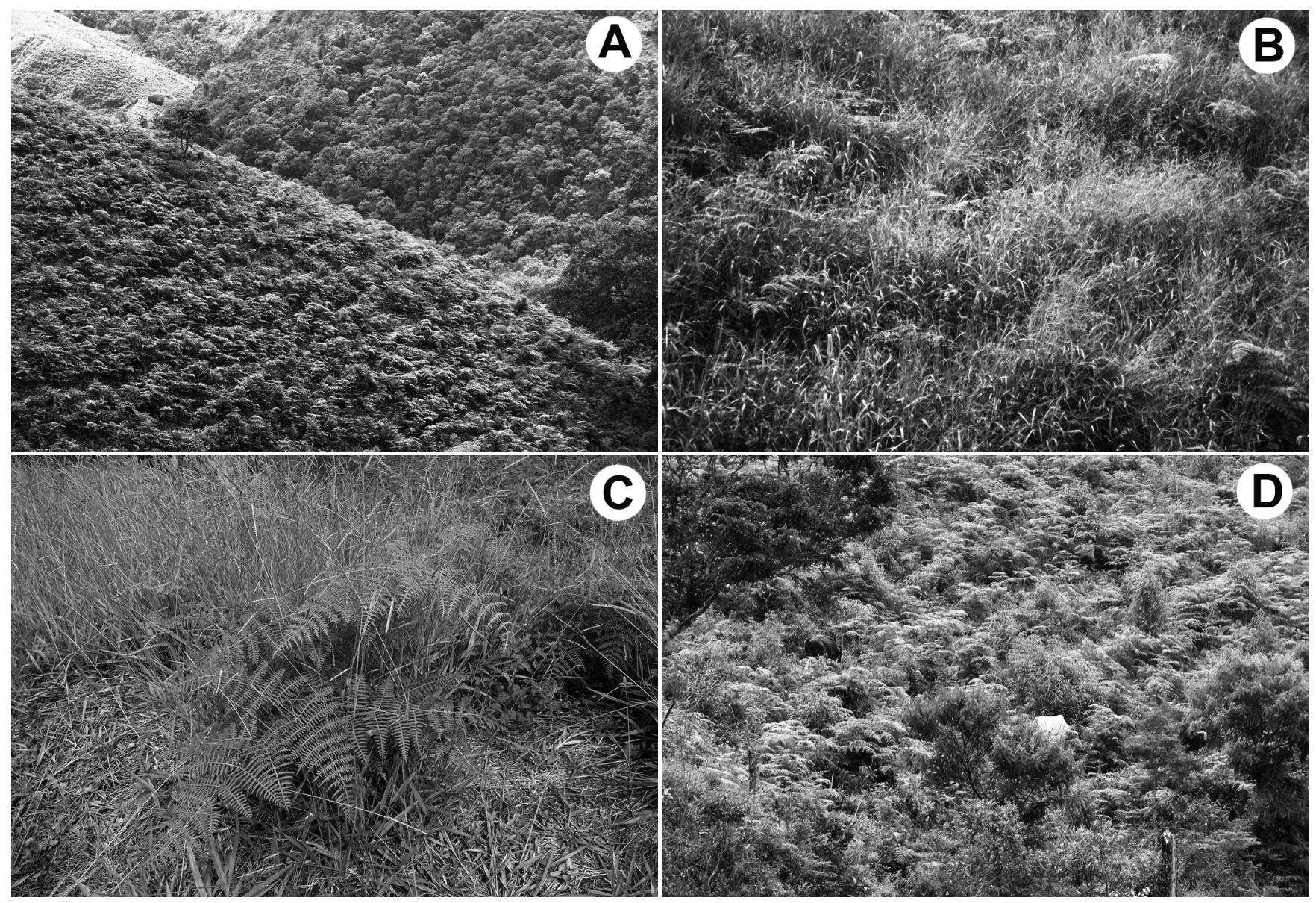

Fig.1. (A) Pastagem severamente invadida por Pterdium arachnoideum. (B,C) Crescimento da samambaia em pastagens recém-formadas por Brachiaria. (D) Bovinos pastando em área muito invadida pela samambaia. Espraiado, município de Passa Vinte, MG.

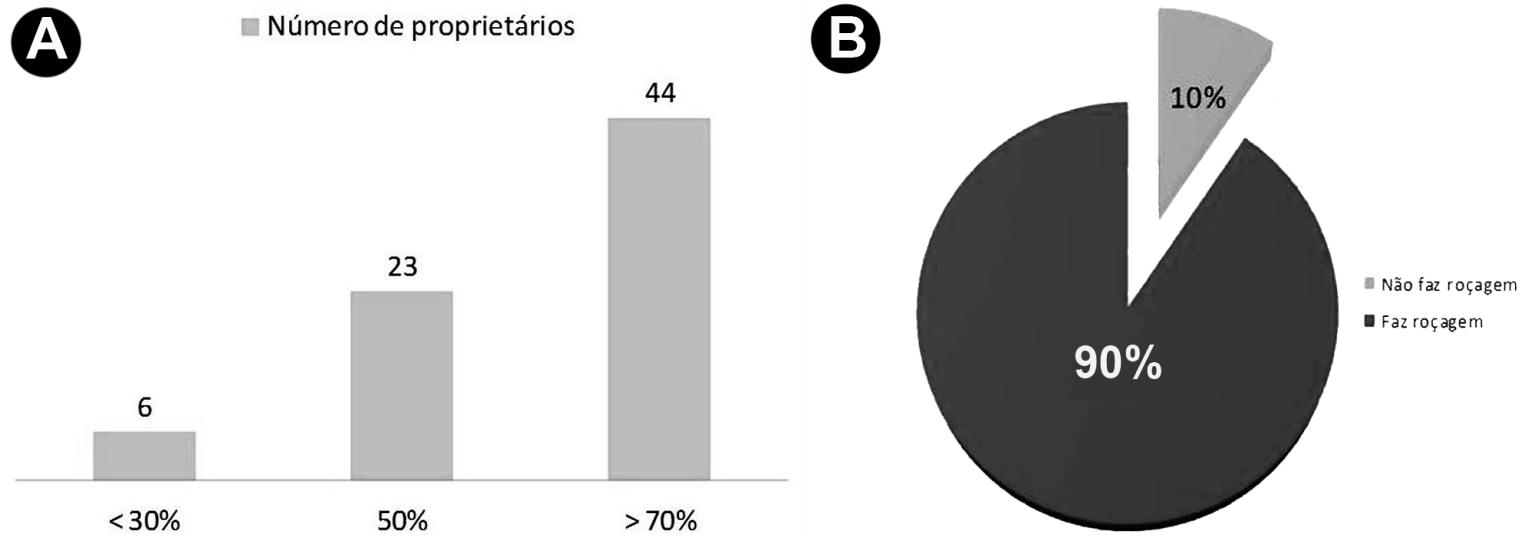

Fig.2. (A) Grau de invasividade das pastagens. (B) Percentual de proprietários que fazem roçagem. 
Dentre os 73 proprietários, nove afirmaram que os animais não ingeriam a planta, 16 diziam que menos de $30 \%$ do rebanho o fazia, 13 deles achavam que em torno de $50 \%$ dos bovinos comia samambaia, enquanto outros 35 eram da opinião que mais de $70 \%$ ou, mesmo, a totalidade dos animais ingeriam a planta (Fig.3A). Entre os 64 produtores que afirmaram que seus animais ingeriam a planta, 19 (30\%) acreditavam que os animais só a comiam quando estavam com fome enquanto $45(70 \%)$ achavam que os animais comiam a planta por vício (Fig.3B).

Quarenta e oito entrevistados acreditavam que esta ingestão se inicia antes do animal completar um ano de idade, 14 achavam que o início da ingestão ocorre até os dois anos e apenas dois citaram que ela só ocorre em animais com idade acima de três anos (Fig.4A). Já em relação ao início dos primeiros sinais clínicos de hematúria, nove entrevistados afirmaram que esses se iniciam antes de o animal completar dois anos de idade, 48 disseram que estes sinais surgem entre 24 e 36 meses de idade e 16 somente perceberam os sinais após 36 meses de idade (Fig.4B).

Das 73 propriedades, em duas não havia animais com hematúria no momento da entrevista. A porcentagem de animais com a hematúria chegou a $70 \%$ em duas propriedades, $50 \%$ em oito propriedades, $20 \%$ em 23 propriedades e até $10 \%$ nas outras 38 propriedades (Fig.5A); 69 (95\%) proprietários disseram que a hematúria pode ser

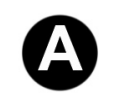

\section{Número de proprietários}
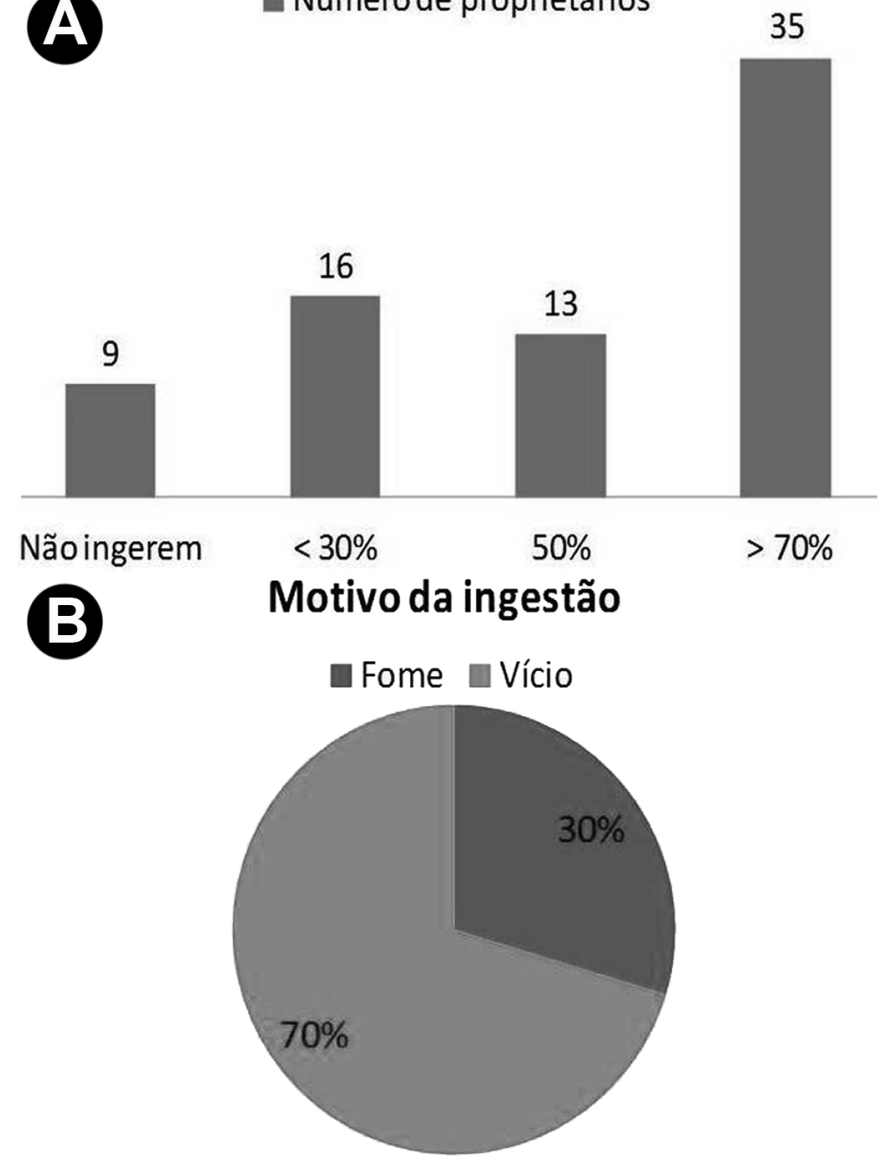

Fig.3. (A) Percentagens dos bovinos que ingerem a samambaia. (B) Motivos da ingestão.
- Número de proprietários

(A)

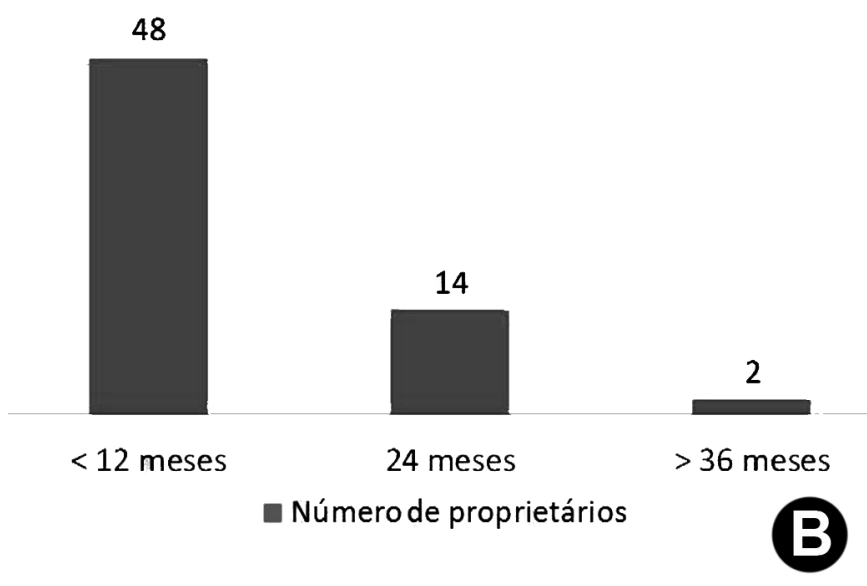

48

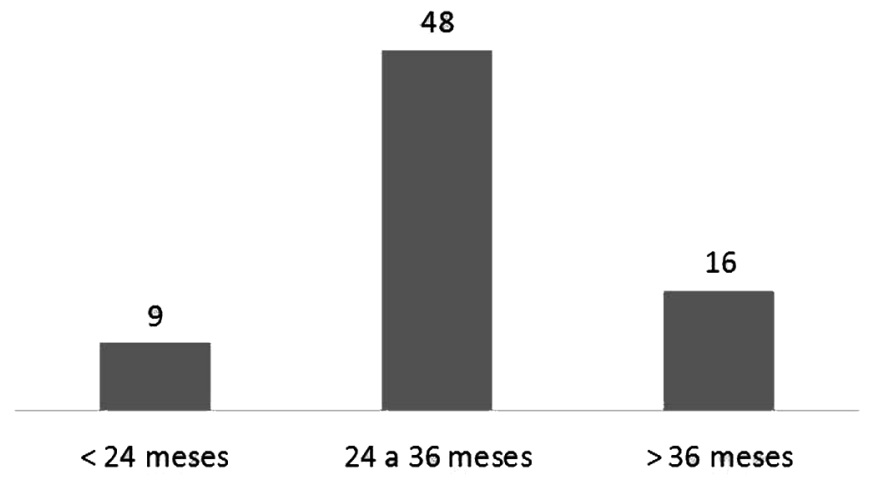

Fig.4. (A) Idade (estimada) em que os bovinos começam a ingerir a samambaia. (B) Idade (estimada) em que são observados os primeiros sinais clínicos de hematúria.

intermitente e quatro (5\%) afirmaram que ela é contínua. (Fig.5B)

Dos 73 entrevistados, 44 usavam algum tipo de medicamento na tentativa de controlar a HEB. Destes, 20 produtores usavam oxitetraciclina injetável periodicamente, oito utilizavam anti-hemorrágicos e antitóxicos, oito usavam produtos fitoterápicos ou caseiros, sete começaram a usar homeopatia e um usava sal mineral alegando que "melhora o problema".

Quando questionados sobre o tempo máximo de sobrevida do animal após o início da hematúria, todos afirmaram que este tempo é bem variado, de um a 60 meses, porém a maioria (46 produtores) é da opinião de que os animais conseguem viver, no máximo, por 24 meses, 19 admitiram que os animais possam atingir 36 meses de sobrevida e oito acreditavam que esses animais possam sobreviver ainda mais tempo (Fig.6). Essa variação, segundo eles, depende de vários fatores listados por ordem de importância: 1) quantidade de sangue eliminado na urina, 2) estado geral do animal, 3) disponibilidade de alimento e 4) uso de oxitetraciclina no início dos sinais clínicos.

Os 73 proprietários têm opiniões divergentes sobre $o$ que causaria a HEB. Foram citadas por 34 (47\%) proprietários que a HEB só apareceu depois da introdução de Brachiaria na pastagem, 15 (20\%) citaram que era a sa- 


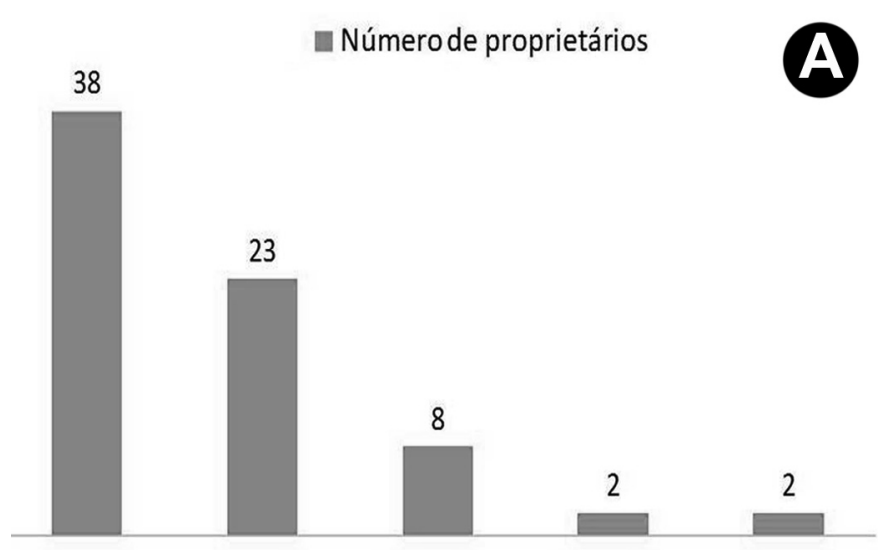

$10 \%$ animais $\quad 20 \%$ animais $\quad 50 \%$ animais $70 \%$ animais Sem hematúria Hematúria clínica Contínua Intermitente

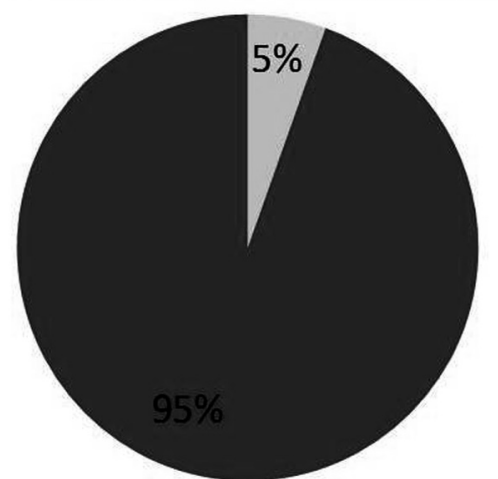

Fig.5. (A) Percentagens de bovinos com hematúria. (B) Percentagens de animais que apresentam hematúria contínua ou intermitente.

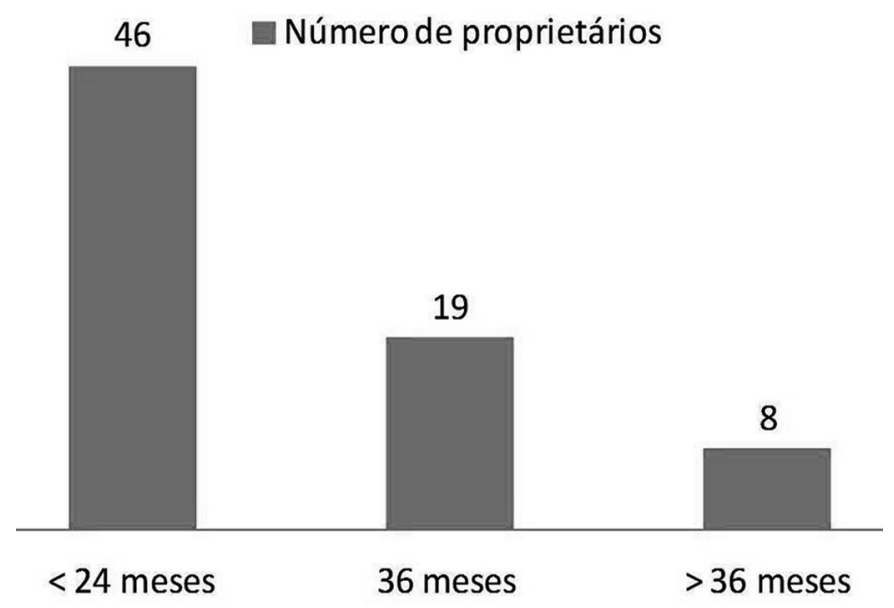

Fig.6. Tempo máximo de sobrevida dos bovinos com HEB após o início dos sinais clínicos.

mambaia, oito (11\%) que era acidez ou alumínio no solo, e o restante (22\%) citam intoxicação por água fria (dois), "água rasa" (um), ingestão de pinhão (um), verminose (um), fraqueza do animal (um), hereditariedade (dois), "rompimento da veia da bexiga" (um), câncer (um) e o restante não sabe a causa (seis). (Fig.7)

De um total de 1.724 animais que estavam nas 73 propriedades visitadas, 200 vacas morreram e 367 foram des-

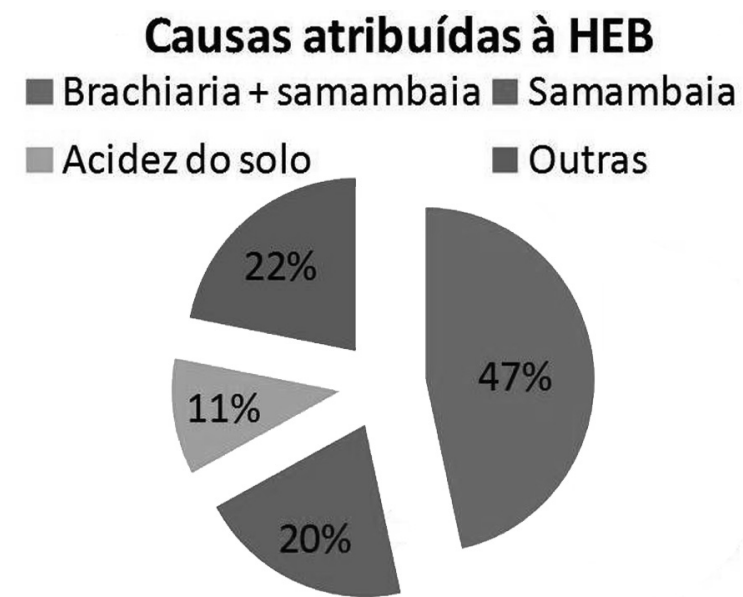

Fig.7. Principais causas atribuídas pelos proprietários à HEB.

cartadas com HEB, ou seja, na média 32,9\% dos animais foram perdidos com uma variação de 18,8 a $50 \%$, dependendo do estabelecimento.

0 preço pago pelos animais de descarte era sempre baixo, em torno de 10 a $20 \%$ do valor de mercado $(\mathrm{R} \$ 250,00$ por cabeça) e, muitas vezes, a venda era condicionada à chegada dos animais vivos ao frigorífico, já que muitos morriam quando eram tangidos ou durante a viagem de caminhão.

Dos 73 entrevistados, 57 (78\%) "conheciam" alguns sinais clínicos dos bovinos com Carcinomas das Vias Digestivas Superiores (CVDS) e 16 (22\%) desconhecian a doença, mas somente cinco $(8,1 \%)$ dos que conheciam a doença já haviam "associado" esta patologia com HEB. Dos 57 (78\%) proprietários que conheciam o problema, 30 (53\%) não sabiam a causa, $15(26 \%)$ acreditavam ser algum tipo de câncer, quatro (7\%) disseram tratar-se "figueira da goela" ou "figueira da boca do bucho", nome popular da papilomatose, e oito (14\%) incriminaram deficiência mineral, pasto ruim e samambaia. (Fig.8A,B)

Sobre a Diátese Hemorrágica (DH), 37 (51\%) dos 73 proprietários não conheciam o problema. Dos 36 (49\%) proprietários que já viram ou tiveram este tipo de manifestação em sua propriedade, 21 (59\%) não sabiam a causa, nove $(25 \%)$ acreditavam que fosse pasteurelose (cinco desses produtores utilizavam vacina contra pasteurelose), três $(8 \%)$ disseram que seria picada de cobra e somente três (8\%) afirmaram que a causa seria a samambaia. (Fig.9A,B)

Nas oito regiões pesquisadas, 25 fazendeiros afirmaram que raramente observaram acidente ofídico com os animais e seis disseram que é relativamente comum. Com relação ao envenenamento ofídico, 18 disseram que os animais "incham" muito no local da picada, nove deles opinam que há hemorragia nas cavidades naturais. Morte súbita, melena e suar sangue apareceram nas respostas em menor frequência.

\section{Estudo retrospectivo de sobrevivência (Grupo I)}

Histórico dos bovinos. Os 26 bovinos do Grupo I, procedentes das Propriedades A, B, C, D, E, F e G, eram animais com hematúria clínica ou com histórico de HEB (relatado pelos proprietários) oriundos de diversas propriedades 


\section{Proprietários que conhecem o CVDS?}

\section{Não conhece a doença}

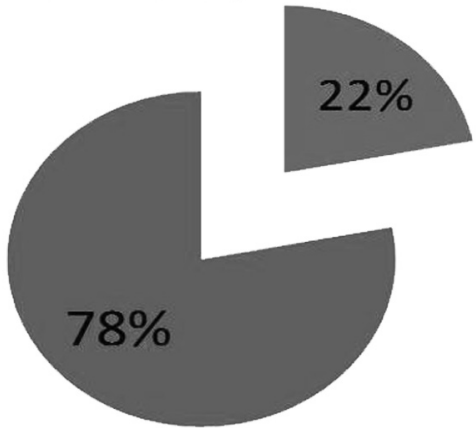

Conhece a doença

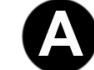

Fig.8. (A) Conhecimento dos proprietários à existência de CVDS.

\section{Proprietários que conhecem a DH?}

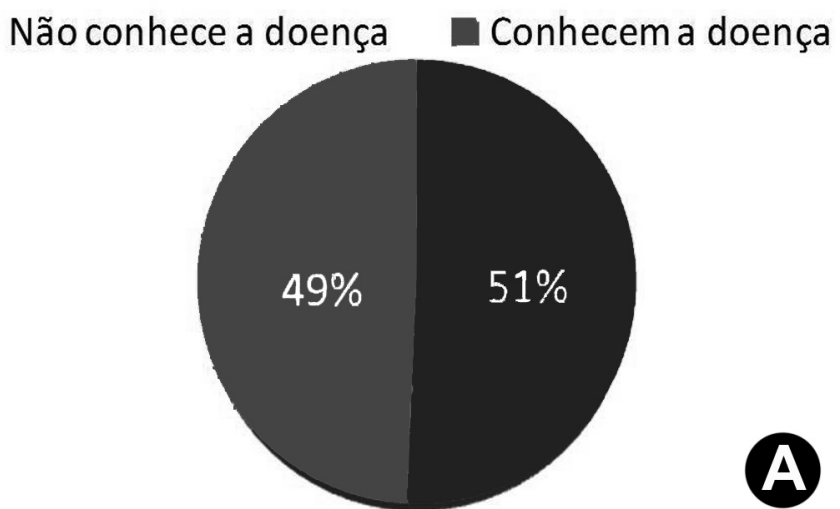

Fig.9. (A) Conhecimento dos proprietários à existência da DH. (B)

infestadas por P. arachnoideum, localizadas no município de Passa Vinte, sul do estado de Minas Gerais. Os animais foram transferidos para a Fazenda Grupo I em 29 de setembro de 2007 e lá permaneceram até 17 de julho de 2009 para observação da sobrevida e da possível recuperação após remoção.

Estes animais chegaram, na maioria dos casos, com baixa condição corporal, foram adquiridos a um preço que variou entre $R \$ 200,00$ e $R \$ 300,00$, valor que, na área, o produtor normalmente recebe por animais acometidos por HEB.

Os principais dados sobre o acompanhamento clínico e os aspectos patológicos dos animais do Grupo I estão descritos no Quadro 1.

Sobrevida. Os 26 bovinos retirados das fazendas de origem tinham entre 18 meses e nove anos de idade; desses, $21(81 \%)$ morreram, três (11\%) foram abatidos e dois (8\%) foram eutanasiados in extremis. Desse total, 18 animais sobreviveram menos de um ano (com 15 mortes, duas eutanásias e um encaminhado ao abate), enquanto os outros oito viveram mais de um ano (com seis mortes e dois abates). 0 período de sobrevida mínimo foi de 15 dias e o máximo foi de 29 meses e 11 dias. (Fig.10A,B)

Aspectos clínicos. Ao exame clínico, 16 bovinos apresentaram hematúria (Fig.11 e 12) contínua e nove hema-

\section{Causas atribuídas à CVDS}

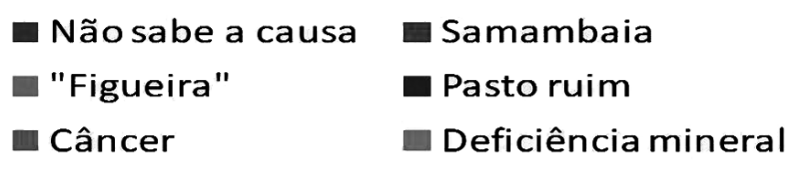

\section{- Pinhão}

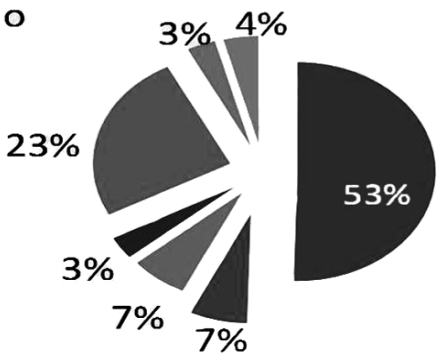

B

(B) Causas atribuídas aos CVDS.

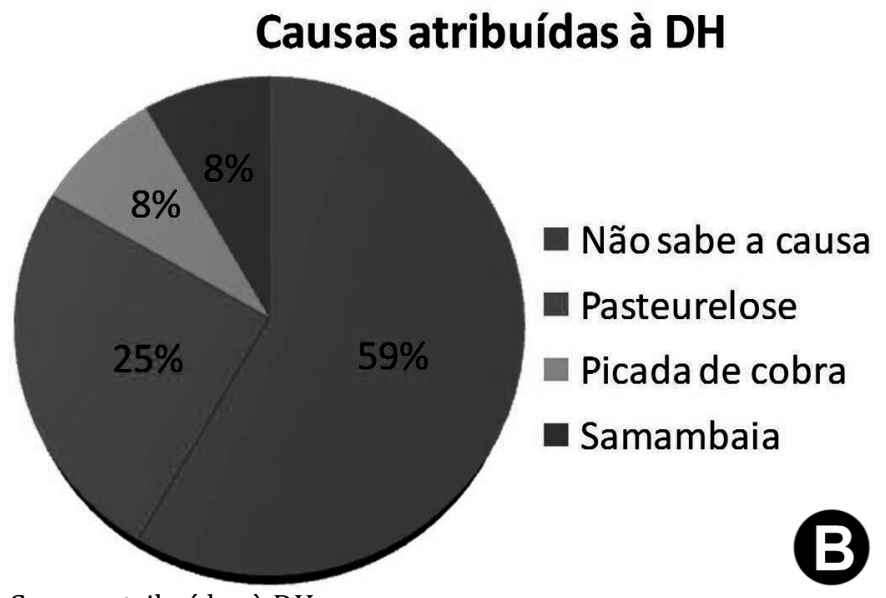

túria intermitente. Um animal deste grupo (Bovino 4) não apresentou hematúria durante o período de observação.

Ao chegarem na Fazenda Grupo I, a condição corporal de 19 animais era CC 1 (magra), em seis animais era moderado CC 2 (moderada) e em apenas um animal era CC 3 (gorda). À época da morte, abate ou eutanásia, a condição corporal de 22 animais era CC 1 , em um animal era CC 2 e em três animais era CC 3 (Fig.13).

Dos 26 animais, nove tiveram, inicialmente, um marcante ganho de peso (CC 3) durante o período de observação. Destes nove animais, contudo, apenas dois mantiveram o peso e foram abatidos com CC 3; dos outros sete, cinco animais morreram, um foi eutanasiado e um foi para o abate, todos com CC 1. (Fig.14 e 15)

\section{Patologia clínica}

Animais com hematúria contínua. Dos 16 animais que apresentavam clinicamente a hematúria contínua, em apenas 11 foram realizados exames hematológicos. 0 hemograma mostrou que na chegada destes 11 animais, apenas dois apresentavam o hematócrito em níveis desejáveis (24 a 40\%); cinco destes 11 animais tiveram seu hematócrito diminuído durante o período de observação, e apenas um animal teve aumento do mesmo (Fig.16). Vale observar que em cinco dos 11 bovinos só foi realizado um hemogra- 


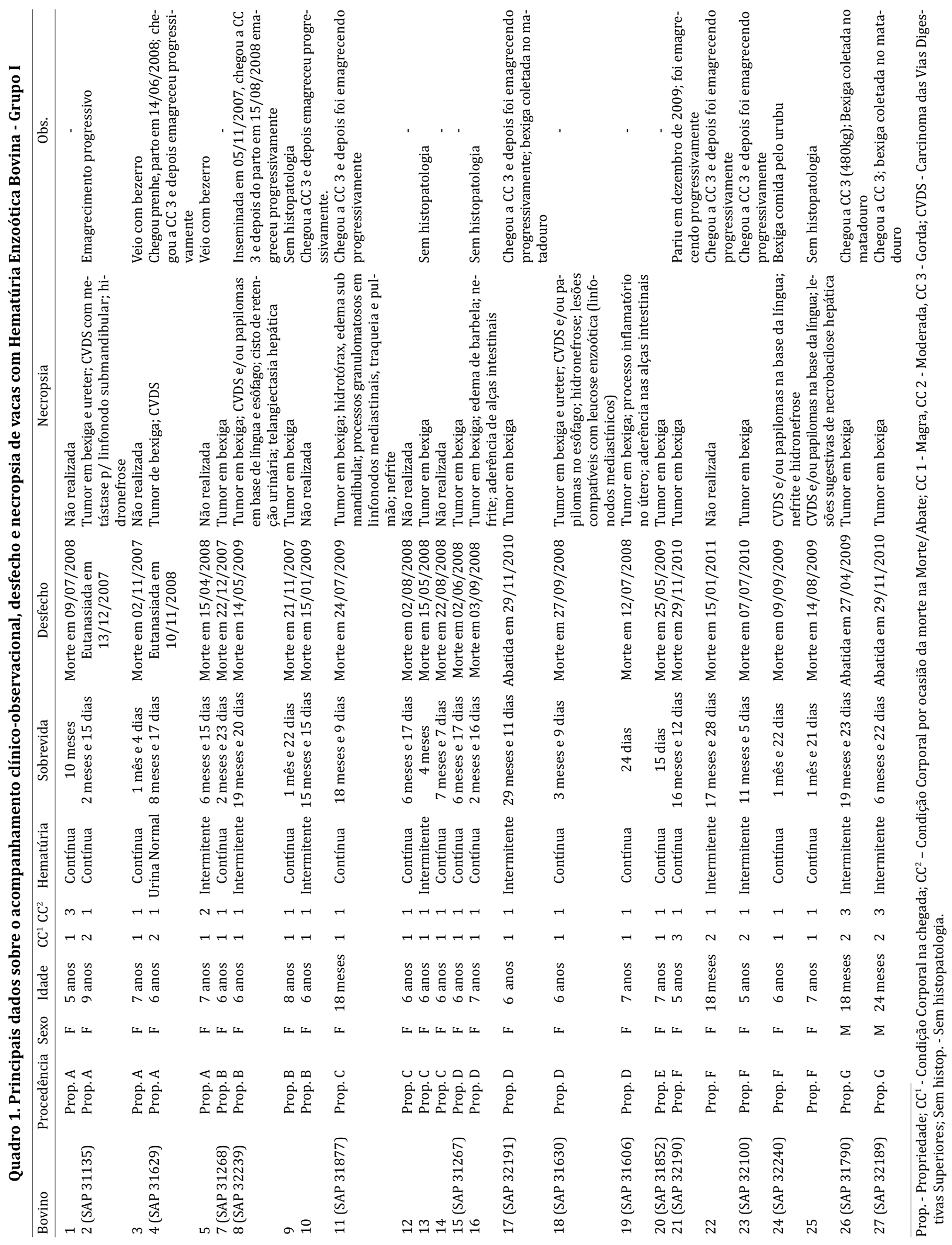




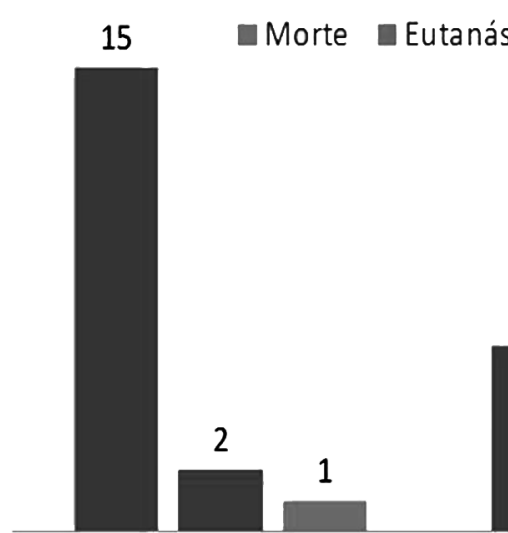

Menos de 1 ano

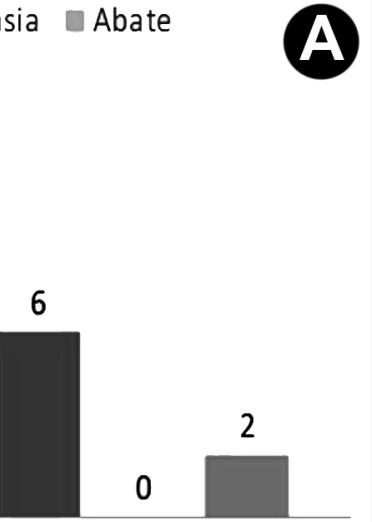

Mais de 1 ano

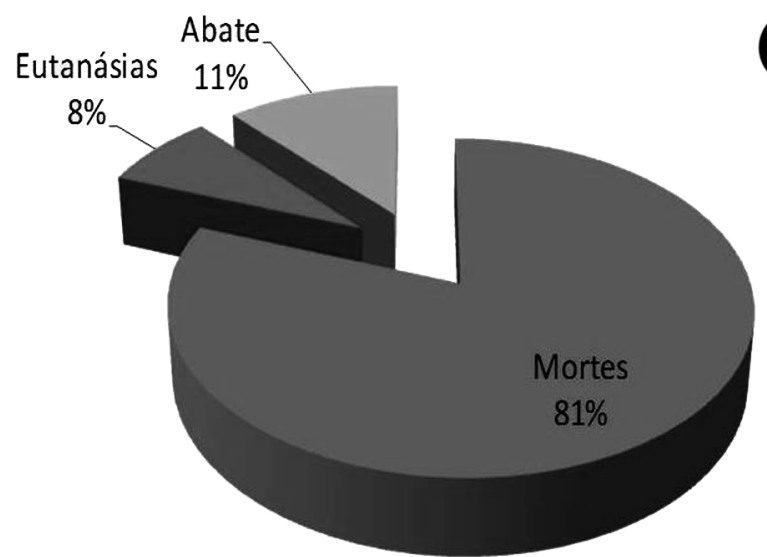

Fig.10. (A) Tempo médio de sobrevida dos bovinos do Grupo I. (B) Percentagens de animais que morreram de forma natural, foram eutanasiados ou abatidos.

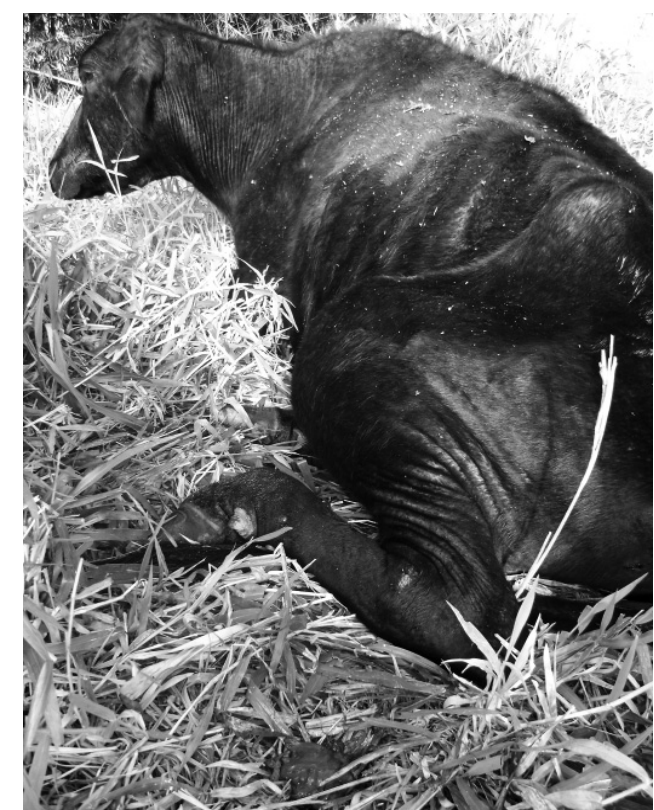

Fig.11. Bovino 25 em decúbito esternal após urinar um coágulo.

ma, pois os animais morreram ou foram abatidos antes da realização de um segundo exame.

0 exame de sedimentoscopia da urina foi realizado em 12 dos 16 bovinos; oito apresentavam hematúria intensa (4+) e quatro hematúria acentuada (3+) (Fig.17).

Animais com hematúria intermitente. Dos nove animais com hematúria clínica intermitente, em oito foram realizados exames hematológicos. 0 hemograma mostrou que seis animais apresentavam o hematócrito em níveis desejáveis (24 a 40\%); cinco animais tiveram o hematócrito diminuído durante o período de observação, dois animais tiveram aumento e um manteve o mesmo valor (Fig.18).

No exame de sedimentoscopia da urina, nove bovinos apresentaram hematúria intermitente, o que está de acordo com o histórico e/ou exames clínicos. Cinco dos nove animais apresentaram hematúria intensa (4+), três animais tiveram hematúria acentuada $(3+)$ e apenas um moderada (2+) (Fig.19 e 20). Ao todo foram realizados 73 exames nos nove bovinos; 55 exames foram positivos e 18 negativos.
Achados de necropsia. Dos 19 animais necropsiados ou que tiveram suas bexigas coletadas no matadouro, 13 apresentavam tumores na bexiga (Fig.21 e 22), quatro tinham tanto os tumores de bexiga quanto o CVDS/Papilomas e dois animais apresentavam os CVDS/Papilomas.

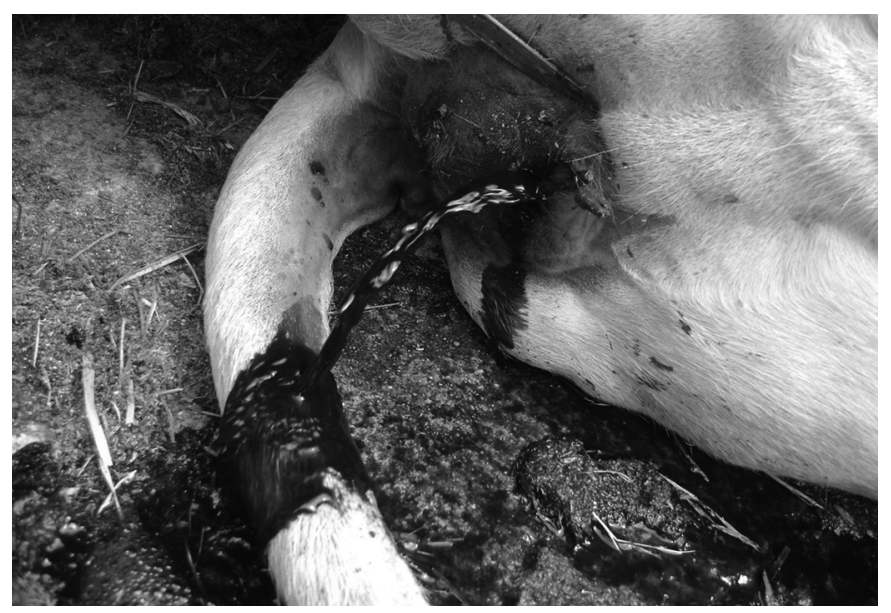

Fig.12. Bovino 20 com hematúria intensa.

- Magra(CC 1) Moderada (CC 2) Gorda (CC 3)

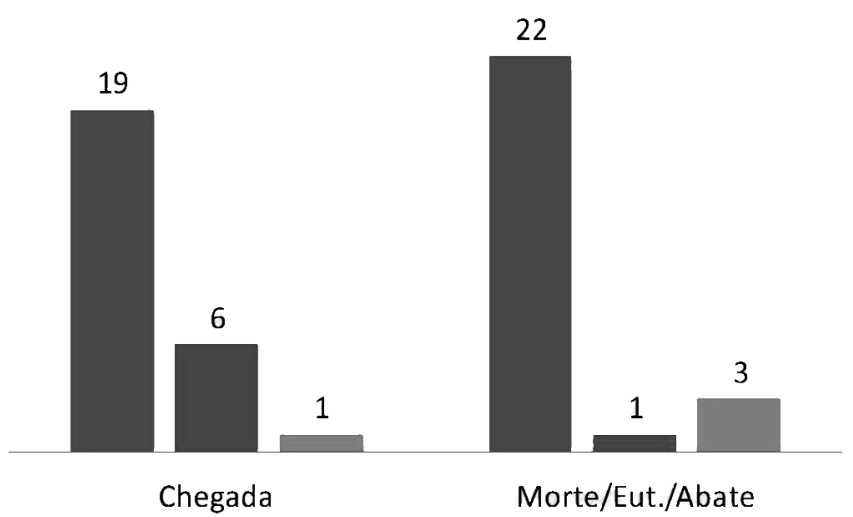

Fig.13. Condição corporal dos bovinos do Grupo I no início da observação clínica (chegada) e por ocasião da na morte, eutanásia ou abate. 

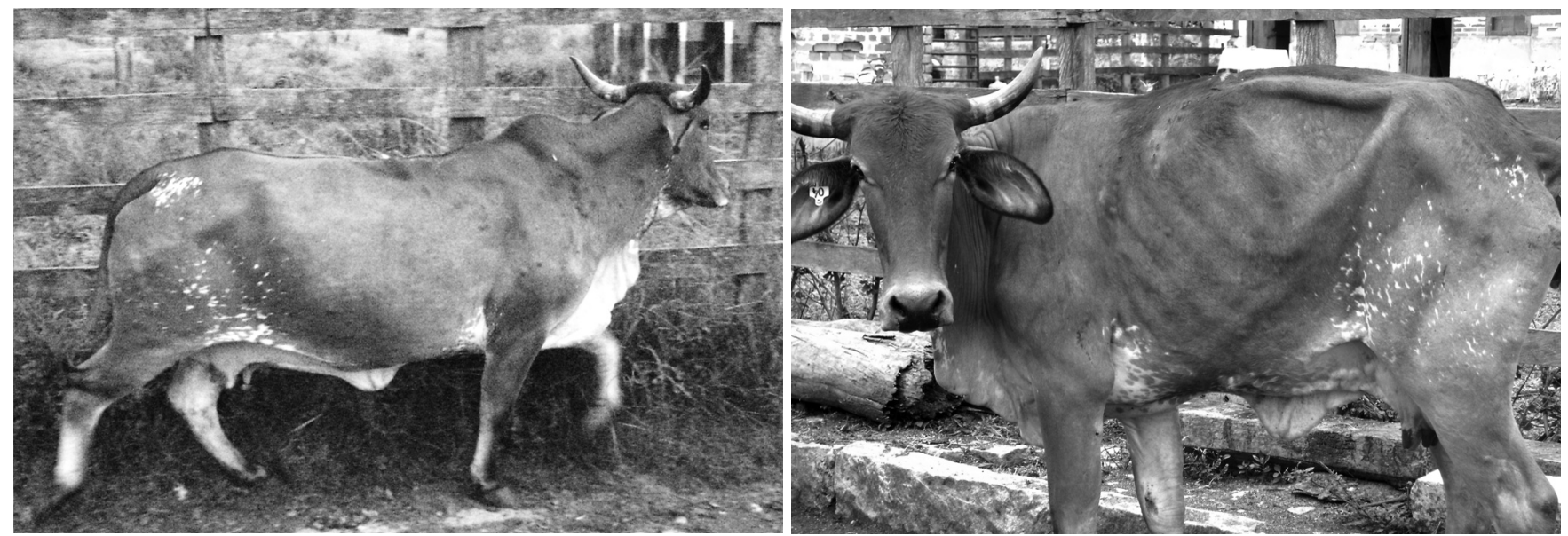

Fig.14. Bovino 4, (A) com CC 3 em período próximo ao parto, (B) com grande perda de peso próximo à morte (CC 1).

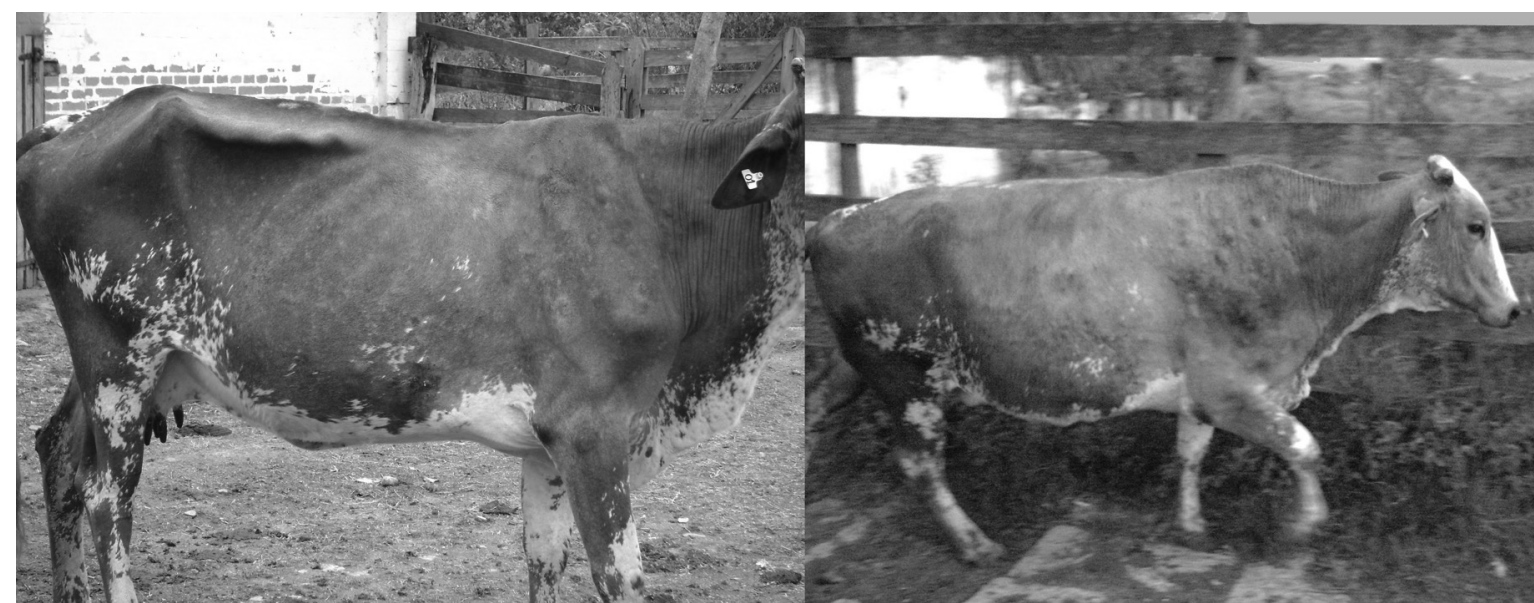

Fig.15. Bovino 1, (A) magro (CC 1), (B) e que teve um melhor ganho de peso durante o período de observação (alcançou CC 3) até a morte.

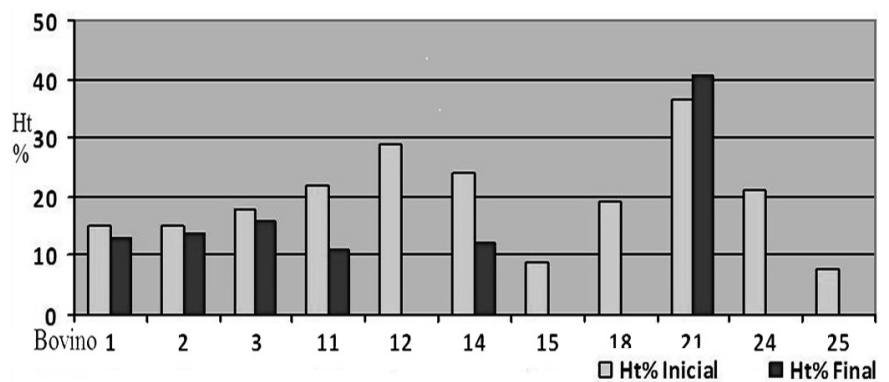

Fig.16. Valores do hematócrito mensurados nos bovinos do Grupo I com hematúria contínua.

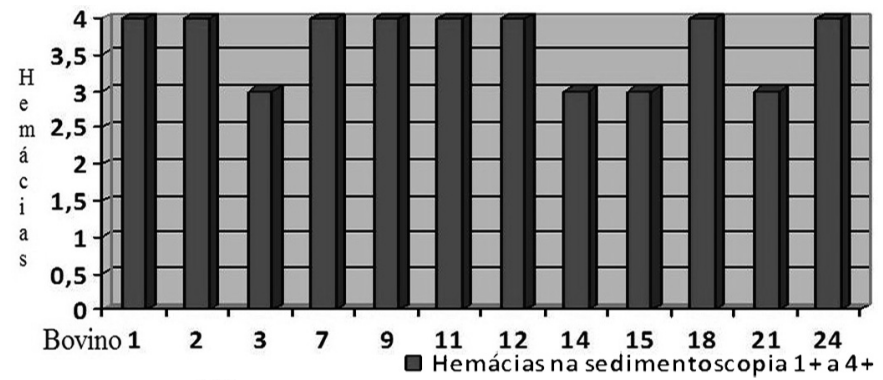

Fig.17. Valores de hemácias na sedimentoscopia da urina de bovinos do Grupo I com hematúria contínua.

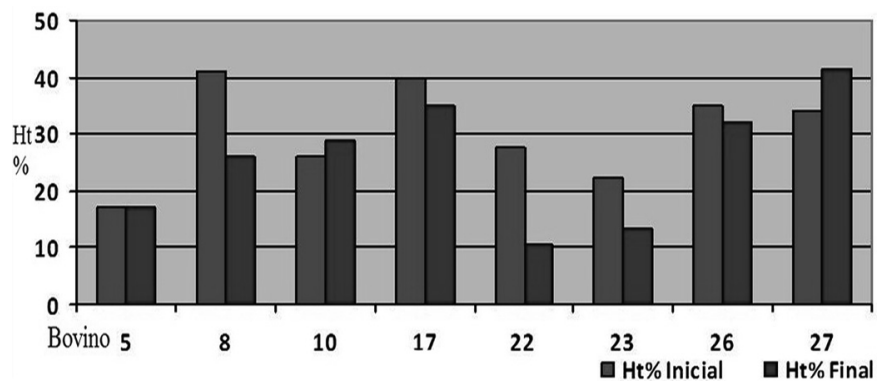

Fig.18. Valores do hematócrito mensurados nos bovinos do Grupo I com hematúria intermitente.

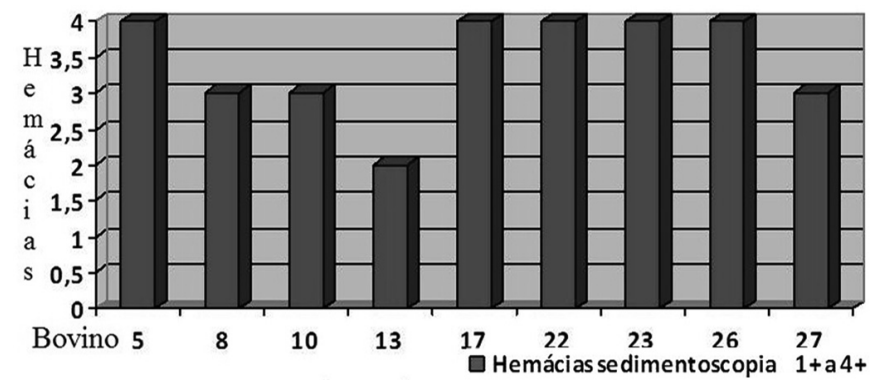

Fig.19. Valores de hemácias na sedimentoscopia da urina de bovinos do Grupo I com hematúria intermitente. 
Outras alterações observadas foram: tumor em ureter, hidronefrose, cisto de retenção urinária, nefrite, necrobacilose hepática, telangiectasia hepática, aderência de alças intestinais, hidrotórax, edema de barbela e processo inflamatório no útero.

Histopatologia. Os principais achados histopatológicos constam no Quadro 2.

\section{Estudo retrospectivo de sobrevivência (Grupo II)}

Histórico dos bovinos. Uma experiência realizada pelo proprietário da Fazenda Vale da Grama, localizada no distrito de Mauá, município de Resende, RJ, cujos pastos eram muito invadidos por $P$. arachnoideum, nos permitiu colher os seguintes dados adicionais sobre o assunto.

Todas as 60 vacas leiteiras, de alto padrão genético, nascidas e criadas na fazenda, desenvolveram HEB. De outras 25 vacas que o proprietário tinha adquirido de fazenda livre de $P$. arachnoideum no município de Porto Real, RJ, e levadas para a fazenda em Mauá, 21 desenvolveram HEB. Dessas 85 vacas, 25 afetadas por HEB foram transferidas para a Fazenda Grupo II, localizada no município de Resende, RJ, cujos pastos são livres de P. arachnoideum com a esperança de se recuperarem.

Em ambas as propriedades o nível nutricional era de excelente padrão com média de produção de $20 \mathrm{~kg}$ de leite/ vaca/dia.
Os principais dados sobre o acompanhamento clínico dos animais do Grupo II estão descritos no Quadro 3.

Sobrevida. Ao serem retiradas da fazenda de origem, as 25 vacas tinham entre três e seis anos de idade, das quais 12 (48\%) morreram e 13 (52\%) foram abatidas. Seis animais morreram em menos de um ano, inclusive o Bovino 43 que morreu durante o transporte entre a Propriedade H (origem) e a Fazenda Grupo II (destino), e 18 tiveram sobrevida maior que um ano, com seis mortes e 12 abates. De uma forma geral, o período total de sobrevida variou entre seis e 54 meses, com tempo médio de 20 meses. Os menores tempos de sobrevida foram o do Bovino 43 (morte no transporte) e o do Bovino 40, que sobreviveu apenas quatro dias após a chegada na Propriedade H (Fig.23.A e B).

Aspectos clínicos. Segundo o proprietário, 13 (52\%) bovinos apresentaram hematúria contínua e nove (36\%) intermitente; sobre três (12\%) animais não houve informação precisa. Ao menos cinco animais foram abatidos devido à hematúria intensa (Fig.24).

Dos 25 animais, na chegada, quatro vacas apresentavam-se com CC 1 (magra), um animal era CC 2 (moderada) e em 20 animais era CC 3 (gorda). À época da morte ou do abate, a condição corporal era CC 1 em 10 animais, CC 2 em cinco animais e CC 3 em 10 animais (Fig.25).

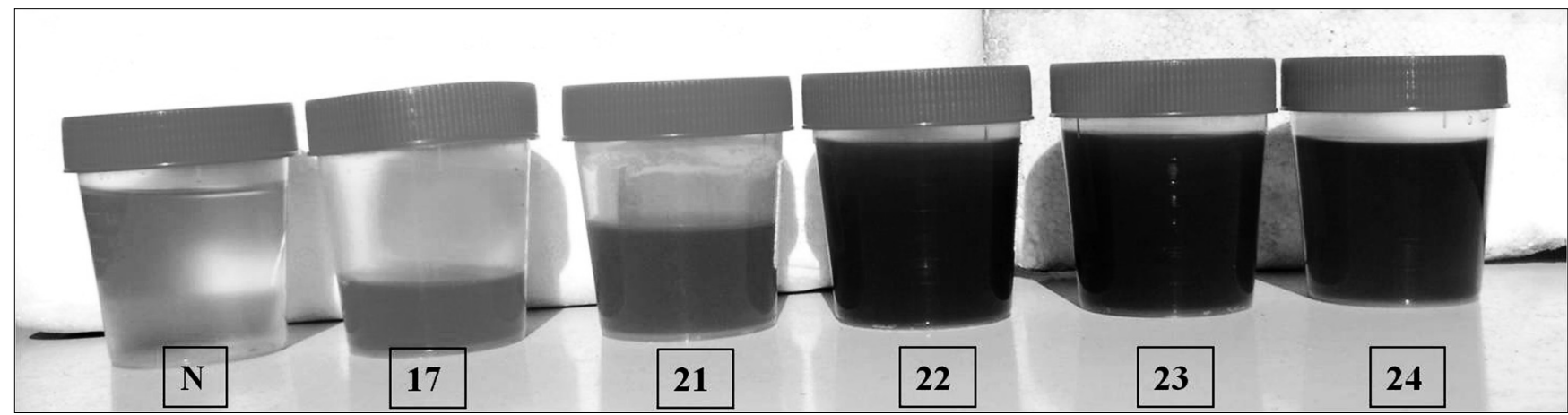

Fig.20. Coleta de urina para realização de urinálise; amostra de urina normal (N) e amostras dos Bovinos 17, 21-24 do Grupo I, com diferentes graus de hematúria.

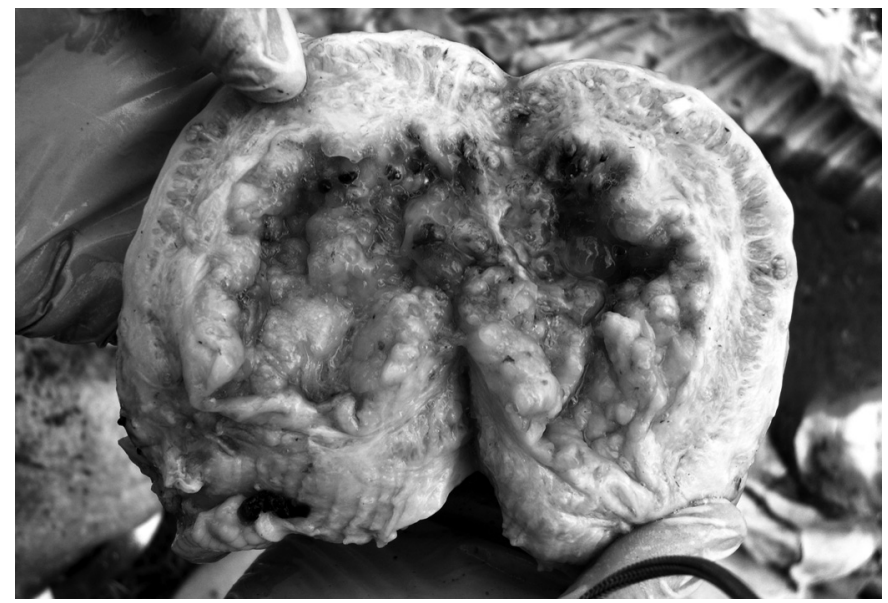

Fig.21. Bovino 13 (hematúria intermitente). Numerosas proliferações na mucosa com acentuado espessamento da parede vesical.

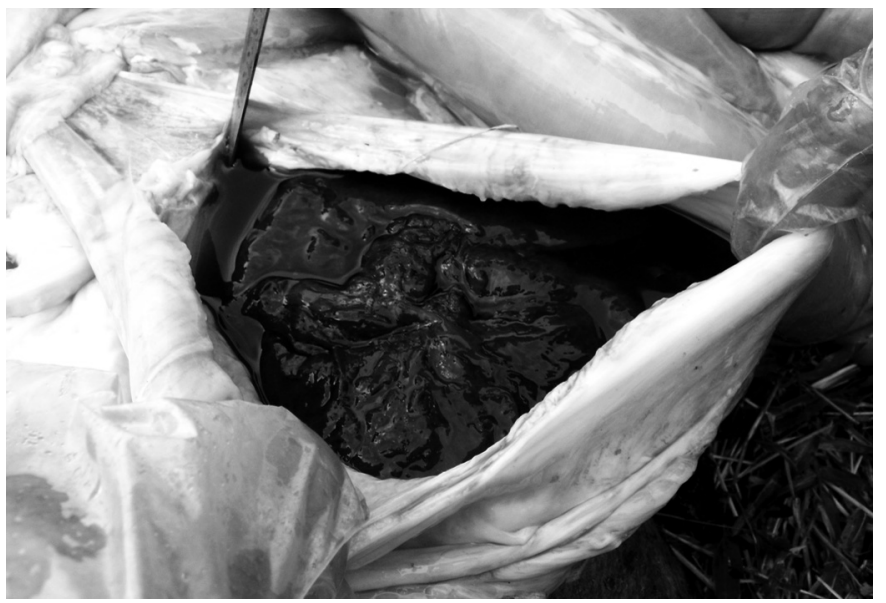

Fig.22. Bovino 20 (hematúria contínua). Bexiga repleta de sangue e com coágulo. 
Três animais ganharam peso durante o período de observação, 10 emagreceram e 12 mantiveram a condição corporal. Das 25 vacas observadas, verificou-se que 16 pariram e, as suas crias nasceram em perfeitas condições de saúde e se desenvolveram normalmente.

\section{DISCUSSÃO}

\section{Sobrevivência dos animais afetados por HEB}

Segundo 48 dos 73 proprietários, o início da ingestão da planta se dá, em geral, com menos de 12 meses de idade e os primeiros sinais clínicos surgem após o primeiro

Quadro 2. Principais achados histopatológicos de vacas com Hematúria Enzoótica Bovina - Grupo I

\begin{tabular}{|c|c|c|}
\hline Bovino & Órgão & Descrição \\
\hline \multirow[t]{3}{*}{$\begin{array}{l}\text { Bovino } 02 \\
\text { (SAP } 31135)\end{array}$} & Bexiga & $\begin{array}{l}\text { Proliferações polipoides com estroma mixomatoso; múltiplos carcinomas uroteliais com grau variado (diferenciação } \\
\text { escamosa e/ou intestinal); hemangioma/hemangiossarcoma. }\end{array}$ \\
\hline & Ureteres & Carcinoma com alto grau de diferenciação pseudoglandular. \\
\hline & Faringe/Palato mole & Carcinoma de células escamosas. \\
\hline \multirow{3}{*}{$\begin{array}{l}\text { Bovino } 04 \\
\text { (SAP 31629) }\end{array}$} & Bexiga & Hemangioma capilar hialinizado; displasia urotelial III ou IV, focal. \\
\hline & Fígado & Leve fibrose portal. \\
\hline & $\begin{array}{l}\text { Laringe/Tonsila } \\
\text { Rim }\end{array}$ & $\begin{array}{l}\text { Carcinoma epidermoide bem diferenciado. } \\
\text { s/a. }\end{array}$ \\
\hline \multirow[t]{2}{*}{$\begin{array}{l}\text { Bovino } 07 \\
\text { (SAP } 31268)\end{array}$} & Bexiga & $\begin{array}{l}\text { Carcinoma esquirroso pobremente diferenciado com áreas de diferenciações mesonefroide, escamosa, intestinal, mi- } \\
\text { neralização distrófica e estroma mixomatoso (focalmente); neoplasia transmural até a serosa. }\end{array}$ \\
\hline & Rim & Fibrose subepitelial na pelve, glomerulonefrite crônica segmental. \\
\hline \multirow{6}{*}{$\begin{array}{l}\text { Bovino } 08 \\
\text { (SAP 32239) }\end{array}$} & Bexiga & Hemangioma capilar malignizado e hemangiossarcoma incipiente. \\
\hline & Faringe/Tonsila & Carcinoma epidermoide incipiente (focal). \\
\hline & Fígado & Congestão passiva crônica e degeneração gordurosa acentuadas (vacuolização). \\
\hline & Pulmão & Focos de broncopneumonia "exsudativa" com presença de larvas de nematódios (foco inflamatório rico em eosinófilos). \\
\hline & Medula óssea & Áreas de rarefação de tecido hematopoiético. \\
\hline & Baço, adrenal & s/a. \\
\hline \multirow[t]{5}{*}{$\begin{array}{l}\text { Bovino } 11 \\
\text { (SAP 31877) }\end{array}$} & Bexiga & $\begin{array}{l}\text { Carcinoma anaplásico; carcinoma de células claras pouco diferenciado (necrose com infecção secundária); carcinoma } \\
\text { epidermoide de células claras; mucosa com metaplasias intestinal e escamosa e neoplasias variadas (carcinomas tra- } \\
\text { becular esquirroso, epidermoide esquirroso, anaplásico, pseudotrabecular, epidermoide, intestinal, apócrino, carci- } \\
\text { noma in situ, displasia urotelial de graus variados; hemangioma cavernoso/capilar, metaplasia apócrina (superfície). }\end{array}$ \\
\hline & Rim & Pielonefrite crônica. \\
\hline & Fígado & Necrose coagulativa paracentral. \\
\hline & Pulmão & Metástases de carcinoma anaplásico (intravascular). \\
\hline & $\begin{array}{l}\text { Córtex com núcleo } \\
\text { caudato, cerebelo }\end{array}$ & Discretos manguitos perivasculares linfo-plasmocitários. \\
\hline $\begin{array}{l}\text { Bovino } 15 \\
\text { (SAP } 31267) \\
\text { Bovino } 17\end{array}$ & Bexiga & $\begin{array}{l}\text { Hiperplasia urotelial com displasia grau II e metaplasia (células cromófobas), acentuada fibrose da submucosa; ulce- } \\
\text { ração focal e inflamação supurativa; foco de carcinoma de transição/epidermoide. }\end{array}$ \\
\hline (SAP 32191) & Bexiga & $\begin{array}{l}\text { Carcinoma urotelial fusocelular ("aspecto de hemangiossarcoma”) com diferenciação escamosa e intestinal; carcino- } \\
\text { ma urotelial; carcinoma urotelial com diferenciação intestinal. }\end{array}$ \\
\hline Bovino 18 & Bexiga & Carcinoma de células escamosas moderadamente diferenciado, parcialmente esquirroso. \\
\hline \multirow[t]{3}{*}{ (SAP 31630) } & Rim & Carcinoma de células escamosas pouco diferenciado. \\
\hline & Pelve renal & Carcinoma in situ; invasão de carcinoma escamoso. \\
\hline & Linfonodo & Metástase de carcinoma escamoso. \\
\hline \multirow[t]{2}{*}{$\begin{array}{l}\text { Bovino } 19 \\
\text { (SAP } 31606)\end{array}$} & Bexiga & $\begin{array}{l}\text { Carcinoma urotelial (urotélio típico com áreas epidermoides/células claras); hemangiossarcoma "esquirroso" (lesões } \\
\text { múltiplas); carcinoma urotelial com diferenciação mesonefroide; carcinoma urotelial com áreas trabeculares e outras } \\
\text { anaplásicas; carcinoma in situ. }\end{array}$ \\
\hline & Rim & Carcinoma in situ na pelve; pielonefrite crônica \\
\hline \multirow{2}{*}{$\begin{array}{l}\text { Bovino } 20 \\
\text { (SAP } 31852)\end{array}$} & Bexiga (autolisada) & Carcinoma urotelial invasivo; carcinoma urotelial com áreas epidermoides, infiltrativo; focos anaplásicos. \\
\hline & $\begin{array}{l}\text { Rim } \\
\text { Medula óssea }\end{array}$ & $\begin{array}{l}\text { Glomerulonefrite segmentar crônica e pielonefrite piogranulomatosa. } \\
\text { Ativa. }\end{array}$ \\
\hline $\begin{array}{l}\text { Bovino } 21 \\
\text { (SAP } 32190)\end{array}$ & Bexiga & Displasia grau II, ulceração do epitélio com infiltração inflamatória mista. \\
\hline Bovino 23 & Bexiga & Hemangiossarcoma moderadamente bem diferenciado; displasia urotelial grau II. \\
\hline \multirow[t]{2}{*}{ (SAP 32100) } & Rim & Leve glomerulonefrite segmentar com dilatação focal túbulos \\
\hline & Fígado & Numerosos focos de “foam cells", degeneração gordurosa (+)+, retenção biliar ++, tumefação de hepatócitos $++(+)$ \\
\hline \multirow{6}{*}{$\begin{array}{l}\text { Bovino } 24 \\
\text { (SAP } 32240)\end{array}$} & Rim & Carcinoma in situ e carcinoma urotelial com diferenciação escamosa; pielonefrite supurativa. \\
\hline & Baço & Moderada hemossiderose. \\
\hline & Faringe/Tonsila & Leve infiltração inflamatória mista e hiperqueratose. \\
\hline & Fígado & Moderada congestão passiva. \\
\hline & Pulmão & Bronopneumonia gangrenosa (supurativa/aspirativa). \\
\hline & Córtex SNC & $\mathrm{s} / \mathrm{a}$ \\
\hline \multirow[t]{2}{*}{$\begin{array}{l}\text { Bovino } 26 \\
\text { (SAP } 31790)\end{array}$} & Bexiga & $\begin{array}{l}\text { Displasia urotelial grau II com focos de células claras; displasia grau III, urotelial, parte escamosa (metaplasia); carci- } \\
\text { noma urotelial infiltrativo (focal) com diferenciação intestinal; carcinoma epidermoide esquirroso; estroma mixoma- } \\
\text { toso focal acompanhado por carcinoma urotelial. }\end{array}$ \\
\hline & $\begin{array}{l}\text { Vesícula seminal/ } \\
\text { Próstata }\end{array}$ & s/a. \\
\hline $\begin{array}{l}\text { Bovino } 27 \\
\text { (SAP } 32189 \text { ) }\end{array}$ & Bexiga & Carcinoma in situ urotelial \\
\hline
\end{tabular}

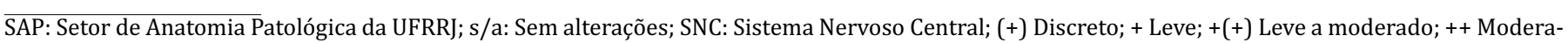
do; ++(+) Moderado a acentuado; +++ Acentuado. 
Quadro 3. Principais dados sobre o acompanhamento clínico e desfecho de vacas com Hematúria Enzoótica Bovina - Grupo II

\begin{tabular}{|c|c|c|c|c|c|c|c|c|c|}
\hline Bovino & Procedência & Sexo & Idade & $\mathrm{CC}^{1}$ & $\mathrm{CC}^{2}$ & Hematúria & Sobrevida & Desfecho & OBS \\
\hline 28 & Prop. H & $\mathrm{F}$ & 4 anos & 3 & 1 & Contínua & 6 meses & Morte & - \\
\hline 29 & Prop. $\mathrm{H}$ & $\mathrm{F}$ & 4 anos & 3 & 1 & Contínua & 13meses & Morte & Pariu logo após a chegada. \\
\hline 30 & Prop. H & $\mathrm{F}$ & 3 anos & 3 & 3 & Contínua & 12 meses & Morte & Chegou seca e pariu; morreu sendo tocada na estrada. \\
\hline 31 & Prop. H & $\mathrm{F}$ & 5 anos & 3 & 1 & Intermitente & 14 meses & Morte & - \\
\hline 32 & Prop. $\mathrm{H}$ & $\mathrm{F}$ & 4 anos & 3 & 1 & Contínua & 12 meses & Morte & - \\
\hline 33 & Prop. $\mathrm{H}$ & $\mathrm{F}$ & 6 anos & 3 & 3 & Contínua & 12 meses & Abate & Não emprenhou (problema reprodução) \\
\hline 34 & Prop. $\mathrm{H}$ & $\mathrm{F}$ & 3 anos & 1 & 1 & Contínua & 10 meses & Morte & Chegou com edema de barbela \\
\hline 35 & Prop. H & $\mathrm{F}$ & 4 anos & 3 & 3 & Contínua & 15 meses & Abate & Veio prenha e pariu \\
\hline 36 & Prop. $\mathrm{H}$ & $\mathrm{F}$ & 4 anos & 3 & 3 & Contínua & 13 meses & Abate & Pariu; hematúria contínua e intensa \\
\hline 37 & Prop. H & $\mathrm{F}$ & 3 anos & 3 & 3 & Contínua & 24 meses & Abate & Pariu, emprenhou e abortou \\
\hline 38 & Prop. H & $\mathrm{F}$ & 6 anos & 2 & 1 & Contínua & 13 meses & Morte & Pariu \\
\hline 39 & Prop. H & $\mathrm{F}$ & 3 anos & 3 & 1 & Intermitente & 24 meses & Abate & Dois partos \\
\hline 40 & Prop. H & $\mathrm{F}$ & 3 anos & 1 & 2 & ---- & 4 dias & Morte & - \\
\hline 41 & Prop. H & $\mathrm{F}$ & 3 anos & 3 & 2 & Contínua & 15 meses & Abate & Pariu \\
\hline 42 & Prop. H & $\mathrm{F}$ & 4 anos & 3 & 2 & Contínua & 13 meses & Abate & Pariu \\
\hline 43 & Prop. H & $\mathrm{F}$ & 4 anos & 3 & 3 & Contínua & 1 dia & Morte & Morreu no transporte \\
\hline 44 & Prop. $\mathrm{H}$ & $\mathrm{F}$ & 6 anos & 3 & 1 & Intermitente & 17 meses & Morte & Uma cria/ano; aumento da hematúria no parto; amanheceu morta \\
\hline 45 & Prop. H & $\mathrm{F}$ & 5 anos & 3 & 3 & ----- & 24 meses & Morte & Morreu com 8 meses de prenhez \\
\hline 46 & Prop. $\mathrm{H}$ & $\mathrm{F}$ & 6 anos & 1 & 1 & Intermitente & 28 meses & Abate & $\begin{array}{l}\text { Apresentou HEB apenas quando era novilha; teve um parto normal } \\
\text { e depois mastite nos } 4 \text { tetos; foi abatida devido à perda de peso; Du- } \\
\text { rante este período chegou ao CC } 3\end{array}$ \\
\hline 47 & Prop. H & $\mathrm{F}$ & 6 anos & 1 & 1 & Intermitente & 33 meses & Abate & Hematúria intensa no momento da morte \\
\hline 48 & Prop. $\mathrm{H}$ & $\mathrm{F}$ & 4 anos & 3 & 1 & ----- & 38 meses & Morte & Dois partos; hematúria intensa no momento da morte \\
\hline 49 & Prop. H & $\mathrm{F}$ & 4 anos & 3 & 2 & Intermitente & 54 meses & Abate & $\begin{array}{l}\text { Boa fertilidade; foi abatida por produzir pouco leite e hematúria in- } \\
\text { tensa }\end{array}$ \\
\hline 50 & Prop. $\mathrm{H}$ & $\mathrm{F}$ & 4 anos & 3 & 2 & Intermitente & 42 meses & Abate & Boa fertilidade, e começou a apresentar hematúria intensa. \\
\hline 51 & Prop. $\mathrm{H}$ & $\mathrm{F}$ & 5 anos & 3 & 3 & Intermitente & 25 meses & Abate & Duas crias; no momento da morte apresentava hematúria intensa \\
\hline 52 & Prop. H & $\mathrm{F}$ & 4 anos & 3 & 3 & Intermitente & 53 meses & Abate & Boa fertilidade; abate devido à hematúria intensa \\
\hline
\end{tabular}

Prop. - Propriedade; CC ${ }^{1}$ - Condição Corporal na chegada; CC ${ }^{2}$ - Condição Corporal na Morte/Abate; CC 1 - Magra, CC 2 - Moderada, CC 3 - Gorda.

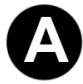

Morte $\square$ Abate

12

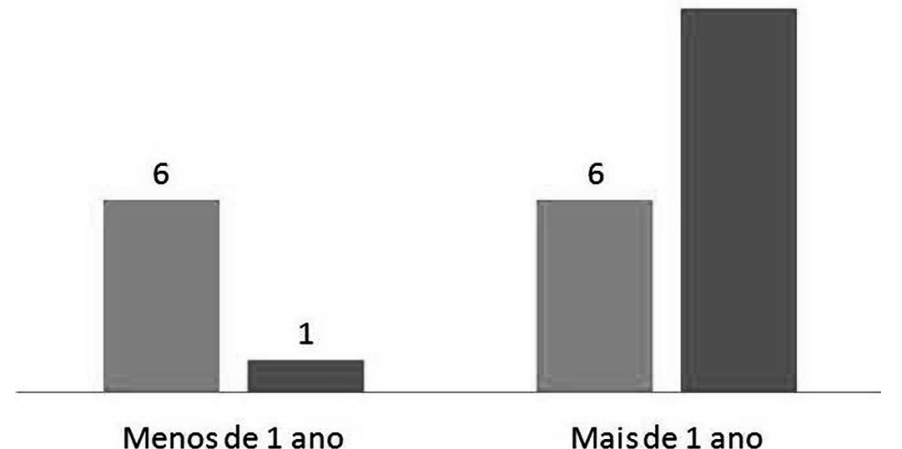

Morte x Abate

B

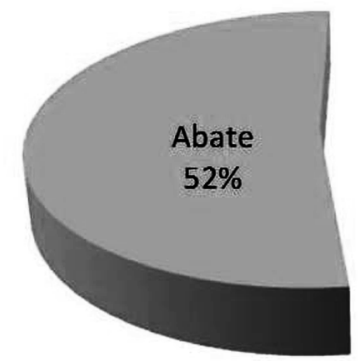

Fig.23. (A) Tempo médio de sobrevida dos bovinos do Grupo II. (B) Percentual de bovinos do Grupo II que morreram de forma natural ou que foram abatidos.

parto nas novilhas ( 24 e 36 meses). 0 tempo mínimo de ingestão para o aparecimento dos sinais clínicos seria, portanto, de aproximadamente 12 a 24 meses. Três animais, porém, já mostraram hematúria aos 18 meses, o que permite inferir que, na dependência das quantidades diárias ingeridas, é possível que tempos de ingestão inferiores a um ano e meio já sejam suficientes para surgirem casos clínicos de hematúria enzoótica bovina (HEB). Em estudos experimentais, o menor tempo necessário para reprodução dessa condição foi de 12 a 15 meses (Rosenberger \& Heeschen 1960).

Nesse estudo obtivemos dados que permitem revisar, pelo menos em parte, alguns aspectos relativos à sobrevi- vência de bovinos afetados por HEB. De acordo com Gründer (2002), a retirada dos animais afetados dos pastos invadidos e boa alimentação levariam a uma lenta recuperação, mas não completa, desde que os animais não estejam em uma fase muito avançada da doença. Considera ainda que os bovinos enfermos poderiam alcançar idade avançada, porém sob o ponto de vista de produtividade, permaneceriam pouco econômicos.

De fato, dos 26 animais do Grupo I, somente dois (7,7\%) alcançaram peso de abate em boas condições corporais; os demais $24(92,3 \%)$ morreram dentro de, no máximo, dois anos. Desses 24 animais, 22 apresentaram quadro clínico de hematúria com evolução para caquexia e morte e apenas 


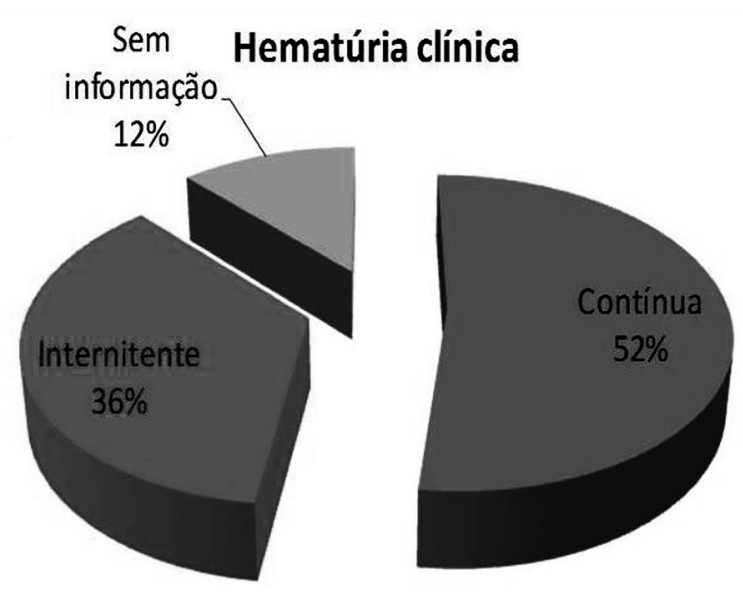

Fig.24. Tipo de hematúria dos bovinos do Grupo II.

- Magra (CC1) Moderada(CC 2) Gorda (CC 3)

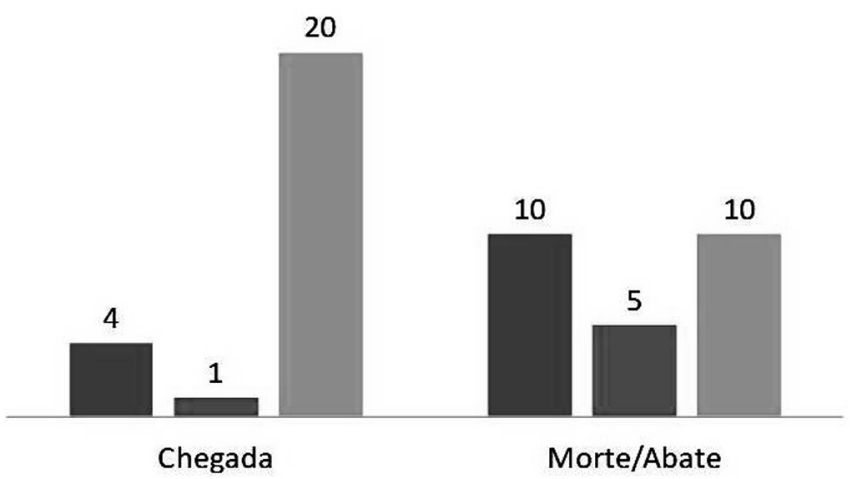

Fig.25. Condição corporal dos bovinos do Grupo II no início da observação clínica (chegada) e por ocasião da na morte ou do abate.

dois estavam em boas condições corporais, quando morreram. Dessa maneira, embora não tenhamos informações sobre o tempo de evolução prévia nos animais do Grupo I, pode-se afirmar que, pelo menos no Brasil, não ocorre recuperação, e sim que a grande maioria dos animais acometidos por HEB não sobrevive até idade avançada. A sobrevida média, nos dois grupos, foi de 20 meses, o que está de acordo com a estimativa dos proprietários submetidos ao questionário, segundo os quais os animais acometidos de HEB sobrevivem por aproximadamente dois anos.

Treze vacas do Grupo II foram abatidas em decorrência de baixo desempenho na produção de leite e na reprodução, por decisão dos proprietários que, receosos de que a doença avançasse e houvesse perda financeira integral, optaram pela venda dos animais por preço bem inferior.

Também na Colômbia, de cinco animais com hematúria enzoótica que foram estabulados e mantidos com alimentação livre de samambaia, todos morreram ou foram eutanasiados in extremis, em períodos que variaram de 33 a 390 dias (Rave et al. 1978).

\section{Prejuízos econômicos associados à HEB}

Embora seja evidente que os prejuízos decorrentes da ingestão de Pteridium arachnoideum são muito significati- vos nas áreas por ela muito invadidas, a mensuração mais exata dessas perdas econômicas é muito difícil. Às mortes determinadas diretamente pela ingestão, devem ser acrescidas as perdas associadas à venda de animais produtivos por uma fração do seu valor, tanto para os vizinhos menos avisados, quanto para os frigoríficos. Adicionalmente há que se computar a menor e progressiva perda da produtividade em vacas afetadas pela enfermidade, como por exemplo, de leite, e o efeito negativo sobre a capacidade reprodutiva.

Durante o levantamento epidemiológico nas regiões, soube-se de um negociante que, no distrito de Fumaça, município de Resende, RJ, vende vacas leiteiras (média de quatro anos de idade) com "garantia", de acordo com a qual, se em até seis meses após a compra o animal começar a urinar sangue, o negócio é desfeito e o dinheiro pago pela vaca é ressarcido.

Outro tipo de negociação conhecida é a "venda condicionada" aplicada por pelo menos quatro negociantes de gado da região de Bocaina e Passa Vinte, MG. Estes compram os animais do produtor, porém só pagam pelo animal caso eles cheguem vivos ao frigorífico e em condições de serem abatidos, caso contrário, os proprietários nada recebem pela venda dos animais. Alguns proprietários inclusive vendem os bovinos por cerca de $\mathrm{R} \$ 200,00(10-15 \%$ do valor de mercado, que gira em torno de $\mathrm{R} \$ 1.500,00 \mathrm{a}$ $\mathrm{R} \$ 2.000,00)$, ou até doam o animal, apenas para que este não morra na propriedade.

Cinquenta e quatro dos 73 entrevistados usam algum tipo de medicação na tentativa de controlar a HEB, o que também contribui para elevar os gastos; entre os medicamentos mais utilizados na tentativa de controle ou tratamento mencionaram-se antibióticos (oxitetraciclina), anti-hemorrágicos, antitóxicos e compostos homeopáticos. Além do gasto direto na aquisição desses produtos, de fato ineficazes para a HEB, deve-se considerar o risco da presença de resíduos de antibióticos na carne e no leite destinados ao consumo humano.

Outro aspecto a ser considerado são os gastos realizados pelos produtores na tentativa de eliminar ou reduzir a invasão da planta nas pastagens; 66 de 73 produtores afirmaram que praticam a roçagem de seus pastos todos os anos, método que se mostra ineficaz visto que o problema nas regiões invadidas pela planta perdura há anos.

\section{Hematúria intermitente $\mathrm{x}$ Hematúria contínua}

Do total de 51 animais com HEB, 29 (56,8 \%) apresentavam hematúria contínua, variando apenas a intensidade, enquanto que em 18 deles $(35,2 \%)$ verificou-se hematúria intermitente. Uma (2\%) vaca do Grupo I (Bovino 4) não apresentou hematúria durante o período de observação e sobre três (6\%) animais do Grupo II não houve informações a respeito.

Segundo alguns, a intermitência pode estar associada a períodos de baixa imunidade, principalmente em fêmeas em idade reprodutiva, pois, por ocasião do parto ocorrem severas alterações hormonais (Bauman \& Curie 1980, Matos 1995). De fato, a proliferação de células neoplásicas pode ser afetada positiva ou negativamente pelo 
status imunitário de seres humanos e animais, e são bem conhecidas diversas doenças imunomediadas desencadeadas pelo marcado efeito que exercem as alterações hormonais sobre o sistema imune de parturientes, como é o caso do lúpus eritematoso sistêmico. Outra possibilidade seria a de que esse efeito possa decorrer por ação direta progressiva sobre o DNA das células expostas ao ptaquilosídeo. Analogamente, embora se trate de um órgão e de um processo patológico bem diferente, tem-se observado que parte dos bovinos com cirrose hepática determinada por pirrolizidinas apresentam quadros clínicos progressivos, mas também com períodos de remissão clínica (Méndez et al. 1987). Essa similaridade talvez decorra do fato de que ambos os agentes, ptaquilosídeo e pirrolizidinas, agem como agentes alquilantes diretamente sobre o DNA das células.

\section{Aspectos etiológicos, patogênicos e patogenéticos}

Outro ponto que deve ser considerado diz respeito à ocorrência de carcinoma in situ na pelve renal de pelo menos três bovinos. No que se refere à macroscopia, por pouco proeminentes, é provável que essas lesões tivessem passado despercebidas; ao que tudo indica a colheita para exame histopatológico só foi feita pelo fato da lesão secundária, pielonefrite piogranulomatosa com dilatação da pelve, ter chamado a atenção.

Dessa forma, é possível que, em parte dos casos de HEB, eventuais lesões neoplásicas ou displásicas, localizadas e pouco conspícuas, possam ocorrer sem serem visualizadas/diagnosticadas não só na pelve, mas também nos ureteres e na uretra. Se esse tipo de lesão pode contribuir ou agravar a hematúria é difícil precisar. Em humanos (Rosai 2004), em cães (Meuten 2002) e em búfalos (Pamukcu 1955) carcinomas de células renais e carcinomas de pelve têm como manifestação frequente a hematúria.

Um dos aspectos mais controversos a respeito da patogênese dos processos neoplásicos induzidos por Pteridium spp. refere-se à eventual participação de agentes do grupo dos Papilomavirus bovino (BPV). Na verdade, a hipótese de etiologia viral ou pela co-participação de vírus como causa dessas neoplasias em áreas invadidas por Pteridium, ao que parece, foi levantada por Olson et al. (1959), em estudos sobre a HEB nos EUA; as tentativas de demonstrar a implicação do vírus da papilomatose na etiologia da HEB resultaram infrutíferas. Jarret et al. (1978a), contudo, também sugeriram que poderia haver participação do vírus do papiloma bovino no desenvolvimento dos CVDS. Essa possibilidade foi testada por Campo et al. (1994), mas os resultados não parecem muito sólidos. Na verdade há diversas evidências que não indicam a participação desses vírus na gênese dos CVDS.

Os principais argumentos utilizados na tentativa de implicar o BPV na etiologia do CVDS e seus respectivos contra argumentos estão listados a seguir:

- A infecção por BPV ocorre em quase todos os rebanhos bovinos (Olson et al. 1959), entretanto a malignização de lesões papilomatosas não foi observada em áreas onde não existe Pteridium aquilinum (Jarret et al. 1978b);

-A hibridização in situ demonstra a presença de BPV em CVDS. Contudo sabe-se que a simples presença de um vírus em determinado tecido não serve como parâmetro para implicá-lo em processos patológicos presentes nesse tecido, sejam eles neoplásicos ou não. Além disso, todas as tentativas de induzir CVDS somente com o BPV falharam; a formação de neoplasias malignas só é possível na presença de Pteridium ou de seu extrato. Já em relação à Pteridium e ao seu princípio tóxico a situação é bem diferente. Não só as mais diferentes neoplasias, em diversos tecidos, de várias espécies animais são facilmente induzidas pela ingestão da planta ou do seu princípio tóxico, como essas neoplasias ocorrem em tecidos não susceptíveis à infecção pelo BPV ou vírus semelhante, espécie-específico. Em outras palavras, parece não haver necessidade da presença de vírus para desenvolverem-se as neoplasias, não só nas vias digestivas superiores como em diversos outros órgãos ou tecidos. Só uma evidência epidemiológica muito forte justificaria a insistência nessa hipótese.

Adicionalmente, estudos mais recentes, realizados em Açores, Portugal, demonstraram através da hibridização in situ que CVDS ocorrem com igual frequência em bovinos infectados e não infectados pelo BPV, ou seja, a presença do vírus é incidental e não há a necessidade de sua presença para que ocorra o CVDS em bovinos (Pinto et al. 2000).

Em outras palavras, porque o ptaquilosideo, por si só, não poderia induzir a formação de papilomas e por continuidade de sua ação provocar a transformação de papilomas em carcinomas?

Se um composto é capaz de induzir neoplasias malignas, porque não poderia produzir benignas e promover sua transformação? Peixoto et al. (2003) citam a transformação de hemangiomas em hemangiossarcomas presentes na bexiga de bovinos com hematúria enzoótica.

\section{Etiologia atribuída à HEB na Região Sudeste}

Entre os 73 proprietários entrevistados não há qualquer consenso em relação à causa da HEB; apenas 15 proprietários (20\%) atribuíram a doença à ingestão exclusiva de Pteridium, enquanto $34(47 \%)$ associam o problema à ingestão da própria Brachiaria decumbens ou entendem que a frequência da enfermidade aumentou após a introdução de Brachiaria, nos anos 70 do século passado.

Essa questão de acreditar ou não que a samambaia é o agente etiológico da HEB é muito importante para a tomada ou não de medidas de controle adequadas. Proprietários que têm pastos severamente invadidos por Pteridium e não acreditaram nessa hipótese dificilmente aceitam medidas profiláticas que incluam ações contra a planta. Por outro lado, o elevado custo de medidas usualmente preconizadas, como aração e calagem, são muito caras e/ou impraticáveis em muitas propriedades.

Por outro lado, muitos proprietários são muito enfáticos em afirmar que "aqui vaca só começou a urinar sangue depois que entrou Brachiaria" ou "isso (urinar sangue) já existia, mas piorou muito depois da entrada de Brachiaria decumbens" (Brust 2003).

De acordo com nutricionistas, $B$. decumbens é muito menos palatável do que o capim-gordura (Melinis minutiflora), gramínea que predominava em áreas de pecuária leiteira 
na região Sudeste, antes da introdução de Brachiaria. Ao que tudo indica, a subdivisão progressiva das propriedades rurais, adicionalmente, aumentou a pressão para que cada vez mais, aumentasse o número de bovinos por unidade de área, de forma que os animais não teriam outra alternativa a não ser aumentar a ingestão de Pteridium, dependendo do pasto em que se encontrem. Fenômeno semelhante verificou-se com Senecio brasiliensis, planta que causa cirrose hepática em bovinos, sobretudo no Rio Grande do Sul. Até a década de 70, de acordo com a maioria dos proprietários e veterinários, bovinos não ingeriam essa planta, de forma alguma. Hoje, dado esse significativo aumento do número de bovinos por unidade de área, e também, mais recentemente, pelas estiagens cada vez mais severas na região, $S e$ necio brasiliensis é a planta tóxica que mais causa mortes de bovinos adultos no RS, da ordem de milhares de cabeças anualmente (Barros et al. 1992, Driemeier \& Barros 1992).

A negação da planta como etiologia da HEB, talvez, em

\section{QUESTIONÁRIO}

\begin{tabular}{|c|}
\hline $\begin{array}{l}\text { Proprietário: } \\
\text { Telefone: } \\
\text { Finalidade da Prod. Leite: ( ) Queijo próprio ( ) Cooperativa / Laticínio ( ) }\end{array}$ \\
\hline $\begin{array}{ll} & \text { Parte I - Eן }\end{array}$ \\
\hline $\begin{array}{l}\text { 1. Já observou bovinos (e outros animais) ingerindo espontaneamente a } \\
\text { samambaia? ( ) Sim ( ) Não }\end{array}$ \\
\hline $\begin{array}{l}\text { 2. Com que frequência? } \\
\text { ( ) Diariamente ( ) De vez em quando }\end{array}$ \\
\hline 3. Qual o numero de animais que ingerem a planta? \\
\hline 4. Qual a categoria de animal(s) que ingere a planta? \\
\hline 5. Em que época do ano? () Seca () Águas ( ) Ano todo \\
\hline $\begin{array}{l}\text { 6. Você acredita que eles ingerem a planta por: } \\
\text { () Vicio ( ) Fome }\end{array}$ \\
\hline
\end{tabular}

Propriedade:

Cap::
Ov.:

Bub Gado de Corte:
Localidade/Município:

№. de vacas: ___ Volume de leite/dia: №. de Matrizes:

\section{Parte II - HEB}

12. Tem observado vacas que urina avermelhado (sangue)?

( ) Sim ( ) Não

13. Que porcentagem do rebanho?

14. Qual a classe de animais afetados?

15. Por quanto tempo os animais urinam sangue?

16. Quantos animais são descartados por ano, por esse motivo?
17. Quantos bovinos morrem urinando sangue?

18. Qual a idade que os animais começam a urinar sangue?

19. É intermitente? () Sim ( ) Não

20. Vai para o abate? ( ) Sim ( ) Não

21. Por que você acha que as vacas urinam sangue?

\section{Parte IV - DH}

32. Já ouviu animais suando sangue? () Sim ( ) Não

33. Em que época do ano?

34. Foi depois de queimadas de pasto?

35. Qual a porcentagem de animais afetados?

36. Desses, quantos morreram?

37. 0 que você acha que é essa doença?

38. Usa vacina contra pasteurelose? ( ) Sim ( ) Não

29. 0 que acontece com esses animais?

30. Já ouviu falar em "favo da goela"?

( ) Sim ( ) Não

31. A que atribui essa doença?

\section{Parte V - Diagnóstico diferencial}

39. Tem ocorrência de picada de cobra nos animais?

( ) $\operatorname{Sim}$ ( ) Não

40. Qual a frequência?

Demais observações
41. Dos animais afetados pela picada de cobra quantos morrem?

42. Quais são os sinais clínicos? 
parte dos casos, seja apenas reflexo da impotência dos criadores frente a ela. Ou seja, essa aceitação implica em aceitar também que o problema praticamente não tem solução, pelo menos para o proprietário com poucos recursos. Outras causas atribuídas à HEB configuram apenas crendices que, no entanto, dão a medida do despreparo em resolver e enfrentar a situação.

\section{Outras considerações}

Um dos aspectos mais relevantes relacionados a este estudo refere-se à intoxicação por Pteridium ou, mais precisamente, à HEB como causa de profundos problemas sócio-econômicos verificados nas regiões por ela mais severamente invadidas. Realmente o efeito/ocorrência de HEB sobre a atividade pecuária, sobretudo de leite é, de forma geral, bastante adverso, contudo, oscila na dependência do grau de invasão das pastagens de leve a muito acentuadas.

As perdas econômicas decorrentes de mortes, abates e diminuição da produção de leite e carne, secundárias a HEB, já descritas há meio século em áreas localizadas na Alemanha, no Brasil alcançam níveis alarmantes por dois motivos. Enquanto na Alemanha a ocorrência de HEB já era rara há décadas, em decorrência do tipo de utilização e cultivo da terra, pelo menos na região sudeste do Brasil a HEB é muito frequente.

Através do questionário verificou-se a situação precária e a impotência dos pequenos produtores rurais frente à doença. Não só a incidência e os prejuízos que por vezes são elevados, como também os criadores não dispõem de métodos viáveis de combate ou profilaxia do problema, mesmo porque muitos se encontram em precárias condições financeiras, decorrente da própria enfermidade o que gera um ciclo vicioso.

Ao que parece esta situação corresponde à de outros produtores rurais em outros países do mundo que praticam pecuária semelhante à nossa e que tenham pastos severamente invadidos por Pteridium.

Na Canadá, por exemplo, a HEB era conhecida como "enfermidade do homem pobre" (Hadwen 1918). Ou seja, a HEB é fator determinante de pobreza no Brasil em áreas severamente invadidas por Pteridium.

\section{CONCLUSÕES}

A grande maioria dos animais afetados pela Hematúria Enzoótica Bovina (HEB) morre em menos de dois anos, mesmo após retirados dos pastos invadidos por Pteridium sp.

A transferência dos bovinos com Hematúria Enzoótica para regiões livres de $P$. arachnoideum é economicamente inviável.

A intermitência da hematúria não pode ser atribuída simplesmente à maior ou menor ingestão da planta ou a períodos de remissão da ingestão, uma vez que o fenômeno ocorre também em animais que não mais estão ingerindo a planta em áreas indenes.
A HEB é causa de sérios prejuízos sócio-econômicos em áreas severamente invadidas por $P$. arachnoideum no Sudeste do Brasil.

\section{REFERÊNCIAS}

Barros C.S.L., Driemeier D., Pilati C. \& Barros S.S. 1992. Senecio spp. poisoning in cattle in Southern Brazil. Vet. Human. Toxicol. 34(3):241-246.

Bauman D.E. \& Currie W.B. 1980. Partioning of nutrients during pregnancy and lactation: a review of mechanisms involving homeostasis and homeorhesis. J. Dairy Sci. 63:1514-1529.

Brust L.A.C. 2003. Comunicação pessoal (Secretaria de Agricultura e Pecuária, Rio de Janeiro, RJ).

Campo M.S., O’Neil B.W., Barron R.J. \& Jarrett W.F.H. 1994. Experimental reproduction of the papilloma-carcinoma complex of the alimentary canal in cattle. Carcinogenesis, New York, 15(8):1597-1601.

Driemeier D. \& Barros C.S.L. 1992. Intoxicação experimental por Senecio oxyphyllus (Compositae) em bovinos. Pesq. Vet. Bras. 12(1/2):33-42.

França T.N., Tokarnia C.H. \& Peixoto P.V. 2002. Enfermidades determinadas pelo princípio radiomimético de Pteridium aquilinum (Polipodiaceae). Pesq. Vet. Bras. 22(3):85-93.

Gründer H.D. 2002. Fütterungs- und vergiftungsbedingte Krankheiten von Harnleiter, Harnblase und Harnröhre, p.731-734. In: Rosenberger G. (Ed.), Innere Medizin und Chirurgie des Rindes. 4.Verf. Parey Verlag, Berlin.

Hadwen S. 1918. Bovine haematuria. J. Am. Vet. Med. Assoc. 51:822. (Apud Heeschen 1959)

Heeschen W. 1959. Die Haematuria vesicalis bovis chronica. Dtsch. Tierärztl. Wschr. 66:622-626, 678-682.

Jarrett W.F.H., Murphy J., O’Neil B.W. \& Laird H.M. 1978a. Vírus-induced papillomas of the alimentary tract of cattle. J. Cancer 22:323-328.

Jarrett W.F.H., McNeil P.E., Grimshaw W.T.R., Selman I.E. \& McIntyre W.I.M. 1978b. High incidence area of cattle cancer with possible interaction between an environmental carcinogen and a papilloma virus. Nature 274:215-217.

Matos L.L. 1995. Perspectivas em alimentação e manejo de vacas em lactação. Anais XXXII Reunião Anual da Sociedade Brasileira de Zootecnia, Brasília, p.147-155.

Méndez M.C., Riet-Correa F. \& Schild A.L. 1987. Intoxicação por Senecio spp. (Compositae) em bovinos no Rio Grande do Sul. Pesq. Vet. Bras. $7(2): 51-56$.

Meuten D.J. 2002. Tumors in Domestic Animals. $4^{\text {th }}$ ed. Iowa State Press, Ames. 788p.

Olson C., Pamukcu A.M., Brobst D.F., Kowalczyk T., Satter E.J. \& Price J.M. 1959. A urinary bladder tumor induced by a bovine cutaneous papilloma agent. Cancer Res. 19:779-782.

Pamukcu A.M. 1955. Investigations on pathology of enzootic bovine haematuria in Turkey. Zentbl. Vet. Med. 2:409-429.

Peixoto P.V., França T.N., Barros C.S.L. \& Tokarnia C.H. 2003. Histopathological aspects of bovine enzootic hematuria in Brazil. Pesq. Vet. Bras. 23(2):65-81.

Pinto C.A., Lima R., Louzã A.C., Almeida V., Melo M., Vaz Y., Neto Fonseca I., Lauren D.R. \& Smith B.L. 2000. Bracken fern induced bovine enzootic haematuria in São Miguel Island, Azores, p.136-140. In: Taylor J.A. \& Smith R.T. (Eds), Bracken-fern: Toxicity, biology and control. Proc. $99^{\text {th }}$ International Bracken Group Conference, 1990, Manchester, UK.

Rave V.G., Sánchez F.O. \& Luque F.E. 1978. Estudio clinicopatologico de la hematuria vesical bovina. Revta ICA, Bogotá, 13(4):671-679.

Rosai J. 2004. Surgical Pathology. $9^{\text {th }}$ ed. Mosby, Edinbourg. 2977p.

Tokarnia C.H., Brito M.F., Barbosa J.D., Peixoto P.V. \& Döbereiner J. 2012. Plantas Tóxicas do Brasil. $2^{\text {a }}$ ed. Editora Helianthus, Rio de Janeiro. 566p. 